\title{
Microbial dynamics in coastal waters of East Antarctica: herbivory by heterotrophic dinoflagellates
}

\author{
Stephen D. Archer ${ }^{1,2,3,4}$, Raymond J. G. Leakey ${ }^{1,4}$, Peter H. Burkill ${ }^{2}$, \\ Michael A. Sleigh ${ }^{3}$ \\ 'British Antarctic Survey, High Cross, Madingley Road, Cambridge CB3 OET, United Kingdom \\ ${ }^{2}$ Plymouth Marine Laboratory, Prospect Place, West Hoe, Plymouth, Devon PI1 3DH, United Kingdom \\ ${ }^{3}$ Department of Biology, University of Southampton, Medical and Biological Sciences Building, Bassett Crescent East, \\ Southampton SO16 7PX, United Kingdom \\ ${ }^{4}$ In collaboration with the Australian Antarctic Division, Channel Highway, Kingston, Tasmania 7050, Australia
}

\begin{abstract}
Heterotrophic dinoflagellates and their herbivory were quantified at a coastal site in East Antarctica in the vicinity of the Australian Antarctic station of Davis $\left(68^{\circ} 35^{\prime} \mathrm{S}, 77^{\circ} 58^{\prime} \mathrm{E}\right)$. The study period, 14 January to 11 February 1994, coincided with the growth and decline of a diatom-dominated phytoplankton bloom. Nine taxa of heterotrophic dinoflagellates, including 2 naked and 7 armoured forms, were identified and selected for the determination of standing stock and grazing rates. All 9 taxa selected for grazing rate measurements showed an increase in abundance and biomass during the phytoplankton bloom. Total abundance and biomass increased exponentially from 14 January to reach a maximum abundance, when the 9 taxa were combined, of $46400 \mathrm{cells}^{-1}$ on the 31 January, equivalent to a standing stock of $114.5 \mu \mathrm{g} \mathrm{Cl}^{-1}$ Taxon-specific grazing rates were determined at in situ predator and prey concentrations by tracing ${ }^{14} \mathrm{C}$ through a 3 compartment (water, phytoplankton, heterotrophic dinoflagellate) model. Mean taxon-specific clearance rates varied more than 10 -fold from $0.028 \mu \mathrm{l} \mathrm{cell} \mathrm{l}^{-1} \mathrm{~h}^{-1}$ in Diplopeltopsis spp. to $0.318 \mu \mathrm{l} \mathrm{cell}^{-1} \mathrm{~h}^{-1}$ in a Protoperidinium sp. In contrast, mean taxon-specific rates of ingestion varied only 3 -fold from $0.72 \mathrm{pg}$ chl a cell-1 $\mathrm{h}^{-1}$ in Diplopeltopsis spp. to $2.38 \mathrm{pg} \mathrm{chl} \mathrm{a} \mathrm{cell}{ }^{-1} \mathrm{~h}^{-1}$ in the same Protoperidinium sp. The total ingestion rate of the 9 taxa was $29.7 \mathrm{ng}$ chl a $\mathrm{l}^{-1} \mathrm{~h}^{-1}$ on 31 January, of which $92 \%$ was consumed by the 3 most abundant taxa, Gyrodinium sp. 1 , Gyrodinium sp.2 and Diplopeltopsis spp. This activity represented $6.7 \%$ of the water column cleared, $4.8 \%$ of autotrophic biomass and $25 \%$ of daily primary production ingested per day. The estimated rates of specific ingestion and growth of heterotrophic dinoflagellates were lower in the coastal waters of East Antarctica than in laboratory studies carried out at higher temperatures. However, when the environmental parameters, predator size and prey type and concentration are taken into account, values measured in the present study are tenable, comparing well with other in situ measurements. Furthermore, the estimates of grazing impact on phytoplankton biomass and production illustrate that heterotrophic dinoflagellates play an important part in the biotic control of phytoplankton production and therefore of carbon flux through the food web of coastal waters of East Antarctica.
\end{abstract}

KEY WORDS: Dinoflagellate - Grazing $\cdot$ Phytoplankton · Antarctica $\cdot$ Carbon

\section{INTRODUCTION}

The magnitude and fate of phytoplankton production potentially influence both the air-sea flux of carbon dioxide (Watson et al. 1991) and the carbon energy

\footnotetext{
-E-mail: r.leakey@bas.ac.uk
}

flow to the pelagic food web (Frost 1991). Heterotrophic protists are now viewed as a dominant biotic control of phytoplankton production in the sea and estimates of their grazing impact indicate that 20 to $100 \%$ of daily primary production is consumed each day (e.g. Gifford 1988, Paranjape 1990, Burkill et al. 1993a, b, 1995, Neuer \& Cowles 1994). The planktonic 
heterotrophic protists that graze phytoplankton are composed of ciliates, sarcodines, actinopods and flagellates, including dinoflagellates (Capriulo et al. 1991). Dinoflagellates make up a major component of the heterotrophic protistan population in both coastal and oceanic waters where they may play a significant role in carbon-energy flow (reviewed by Lessard 1991. Sherr \& Sherr 1994)

Heterotrophic nutrition patterns in dinoflagellates are diverse and the strategies employed include auxotrophy, mixotrophy and osmotrophy (Gaines \& Elbrächter 1987). In the present study, the term heterotrophic dinoflagellate is used to describe those species that are obligate heterotrophs and lack chloroplasts. There is evidence that planktonic dinoflagellates feed on a prey size spectrum ranging from bacteria (Lessard \& Swift 1985) to large diatoms (e.g. Hansen 1992), copepod eggs (Sekiguchi \& Kato 1976) and even early naupliar stages of copepods (Jeong 1994). The ability of dinoflagellates to feed on such a wide size spectrum of prey may reflect the variety of feeding mechanisms that they employ. Three mechanisms of feeding on phytoplankton have been described: ingestion of entire cells (phagotrophy sensu stricto); use of a peduncle to pierce prey cells and suck out the cell contents (myzocytosis); and deployment of a cytoplasmic veil to enclose prey cells within which digestion of the prey occurs (pallium feeding) (reviewed by Elbrächter 1991).

A variety of direct and indirect methods have been used to estimate the herbivory of heterotrophic protists (Gifford 1988, Landry 1994). However, few methods directly demonstrate the role of the different taxonomic components of the microbial community. Of those that do, the most commonly applied technique involves the use of inert particles, in particular fluorescently labelled heat-killed algae, as tracers of ingestion (Rublee \& Gallegos 1989). This technique is not applicable to heterotrophic dinoflagellates that may feed by myzocytosis or deployment of a pallium because they do not transport particles into the main cell body. Instead, Lessard \& Swift (1985) developed a dual-radioisotope method to trace dinoflagellate clearance rates on ${ }^{3} \mathrm{H}$-labelled bacteria and ${ }^{14} \mathrm{C}$-labelled phytoplankton. However, in situ studies remain rare and direct measurements of dinoflagellate grazing rates are almost exclusively restricted to monospecific laboratory cultures grazing on a low variety of prey species.

Explanations for the 'Antarctic paradox' of low phytoplankton growth despite high ambient nutrient concentrations in the Southern Ocean (reviewed in Priddle et al. 1992, Tréguer \& Jacques 1992) have largely focused on aspects of possible bottom-up control of phytoplankton production. However, modelling studies of food web dynamics (e.g. Becquevort et al. 1992, Murphy et al. in press), microcosm experiments (Kuparinen \& Bjørnsen 1992) and quantification of herbivory by the dilution technique (Burkill et al. 1995) have suggested that heterotrophic protists may play a significant role in the top-down control of phytoplankton production in the Southern Ocean. Despite the obvious importance of protist grazing in temperate and tropical waters the number of direct measurements of the grazing rates of Antarctic protists remains limited.

The Southern Ocean is generally regarded as a region of low primary productivity (Jacques 1989); however, enhanced production is often found associated with the receding marginal ice zone (Smith 1987. Arrigo \& McClain 1994) and in coastal waters (Hayes et al. 1984). Prydz Bay (approximately $68^{\circ} \mathrm{S}, 75^{\circ} \mathrm{W}$ ) comprises a relatively shallow continental shelf. region and is an active site of Antarctic Bottom Water formation (Middleton \& Humphries 1989). Seasonally, the waters of Prydz Bay appear to support a high phytoplankton biomass and there is evidence that large heterotrophic dinoflagellates are an active component of the plankton throughout the inner shelf region (Kopczynska et al. 1995). In common with other Antarctic coastal waters (e.g. Knox 1990, Satoh et al. 1991, Clarke \& Leakey in press), the seasonal cycle of microbial production in Prydz Bay is closely coupled to insolation and to sea ice formation and melting. Highest microbial abundance occurs shortly after ice melt in spring and continues during a short ice-free summer period (Perrin et al. 1987, Davidson \& Marchant 1992).

With a number of modifications, we have employed a similar technique to that used by Lessard \& Swift (1985) to estimate the in situ grazing rates of heterotrophic dinoflagellates on phytoplankton in the coastal waters of Prydz Bay. In particular, we aimed to determine the impact of dinoflagellate herbivory on primary production during the growth and decline of a summer phytoplankton bloom. The present study formed part of a coordinated programme to measure microbial productivity and estimate the importance of heterotrophic protists to carbon-energy flow in the coastal waters of Antarctica. Concurrent studies were undertaken on the net microbial community production (Robinson et al. unpubl.), ciliate herbivory (Grey \& Leakey unpubl.) and bacterivory by heterotrophic nanoflagellates (Leakey et al. in press).

\section{MATERIALS AND METHODS}

Sampling. Sampling was undertaken during the austral summer from 14 January to 11 February 1994 at a coastal location in the vicinity of the Australian Antarctic station of Davis $\left(68^{\circ} 35^{\prime} \mathrm{S}, 77^{\circ} 58^{\prime} \mathrm{E}\right.$ ) (Fig. 1) 
Fig. 1 Map of study area showing location of sampling site (O) at O'Gorman Rocks in the vicinity of the Australian Antarctic station of Davis

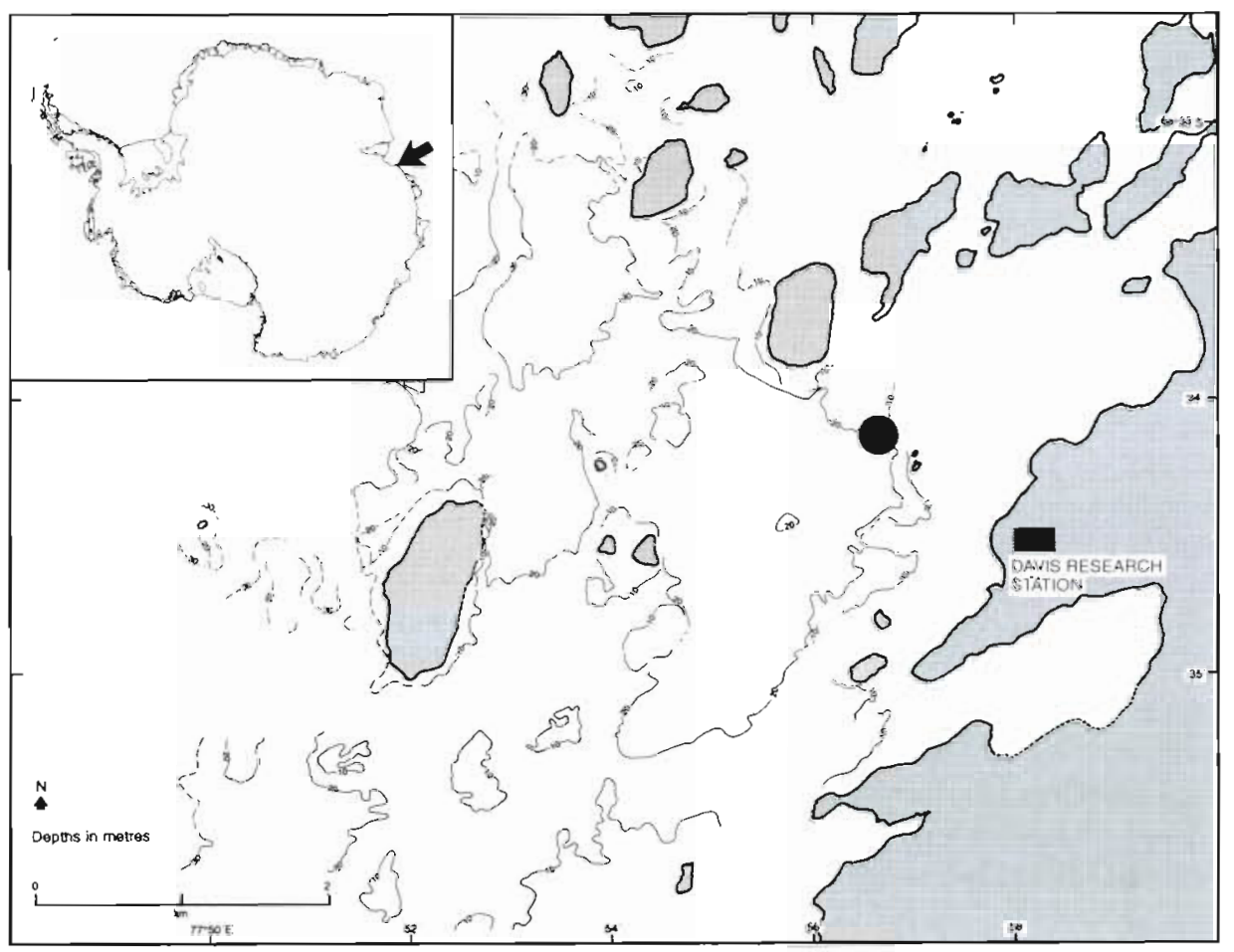

During the study period open water conditions prevailed and sampling was carried out at a fixed site approximately twice weekly from a hard boat. The water depth at the sampling site was approximately $22 \mathrm{~m}$. On each sampling occasion $10 \mathrm{l}$ of water was collected in an acid-washed opaque polypropylene aspirator from a depth of $5 \mathrm{~m}$ using an acid-washed $5 \mathrm{l}$ Go-Flo bottle, and used for the determination of autotrophic biomass, dinoflagellate taxonomy, standing stock and herbivory as outlined below. Water temperature was measured at regular intervals throughout the study period using a Platypus CTD (Platypus Engineering, Tasmania).

Autotrophic biomass. In order to estimate autotrophic biomass, triplicate $500 \mathrm{ml}$ subsamples were filtered onto $G F / F$ filters for the determination of chlorophyll a concentration. Pigments were extracted in $90 \%$ acetone for $24 \mathrm{~h}$ in the dark and absorbance measured with a spectrophotometer according to Strickland \& Parsons (1972). Autotrophic biomass was calculated using a carbon:chlorophyll ratio of 46 , the mean value determined by Hewes et al. (1990) for water samples collected from various sites throughout the Southern Ocean.

Heterotrophic dinoflagellate taxonomy, abundance and biomass. Dinoflagellate taxa were initially identified as heterotrophic forms by examination of live samples using epifluorescence microscopy. Heterotrophic dinoflagellates lacked the bright red to yellow-orange fluorescence of autotrophic forms and generally fluoresced green or yellow under blue light (Lessard \&
Swift 1986, Shapiro et al. 1989, Bralewska \& Witek 1995). Dinoflagellate identification was based on the classifications by Balech (1975) and Dodge (1982). Taxa were enumerated from settled samples examined by inverted microscopy (Utermöhl 1958). On each sampling occasion duplicate $250 \mathrm{ml}$ subsamples were fixed with Lugol's iodine to a final concentration of $1 \%$. The 2 subsamples were pooled and duplicate $50 \mathrm{ml}$ aliquots were concentrated by settling for $48 \mathrm{~h}$ and enumerated at $\times 200$ magnification.

Cell volumes were determined from $1 \%$ Lugol's fixed samples by image analysis using a Seescan Solitaire Plus system (Seescan plc, Cambridge, UK) (see Archer et al. 1996 for details). Both naked and armoured dinoflagellate carbon biomass was calculated from cell volume using a conversion factor of $140 \mathrm{fg}$ $C \mathrm{~mm}^{-3}$ (as quoted in Lessard 1991).

Heterotrophic dinoflagellate herbivory. A modification of the technique used by Lessard \& Swift (1985) based upon the exchange of radioisotope in a 3-compartment model (Daro 1978) was used to measure the taxon-specific uptake rates of photosynthetically fixed ${ }^{14} \mathrm{C}$ by heterotrophic dinoflagellates at in situ predator and prey concentrations. Daro's (1978) simplified model of radioisotope exchange is described by:

water phytoplankton

heterotrophic dinoflagellate

$$
-\lambda_{1} \rightarrow \quad-\lambda_{2} \rightarrow
$$

$q_{1}$

$q_{2}$ 
where $q$ is the concentration of radioisotope in each compartment and $\lambda$ the rate of isotope exchange between compartments. Grazing rates $\left(\lambda_{2}\right)$ can then be approximated by:

$$
\lambda_{2}=\frac{2 \times q_{3}}{q_{2} \times t}
$$

where $t$ is the incubation time

Daro's (1978) model assumes that the uptake of radioisotope by the phytoplankton is linear over time, that the concentration of ${ }^{14} \mathrm{C}$ remains high in the water compared to the phytoplankton and dinoflagellate compartments and that no recycling of ${ }^{14} \mathrm{C}$ occurs within the system.

For each experiment, water siphoned from the $10 \mathrm{I}$ aspirator using darkened silicon tubing was used to rinse and then fill an acid-washed $125 \mathrm{ml}$ polycarbonate bottle. $500 \mu$ l of stock $\mathrm{NaH}^{14} \mathrm{CO}_{3}$ (Amersham International plc) was added to give an estimated final radioisotope activity of $1 \mu \mathrm{Ci} \mathrm{ml^{-1 }}\left(37 \mathrm{kBq} \mathrm{ml} l^{-1}\right)$. To determine the ${ }^{14} \mathrm{C}$ activity added to each incubation $\left(q_{1}\right)$ the sample was mixed and a $250 \mu \mathrm{l}$ subsample removed to a scintillation vial containing $500 \mu \mathrm{I}$ of phenethylamine. Incubations were carried out in situ, commencing at mid-morning and lasted from 6 to $9 \mathrm{~h}$. At the end of an incubation, samples were transported quickly ( $<15 \mathrm{~min}$ ) in the dark and at in situ temperatures to the laboratory for processing. The incubation time up to the commencement of filtration procedures was used to calculate grazing rates.

To determine the extent of particulate photosynthetic incorporation of ${ }^{14} \mathrm{C}\left(q_{2}\right)$, two $10 \mathrm{ml}$ subsamples were filtered through polycarbonate filters of $2.0 \mu \mathrm{m}$ pore size at less than $2.5 \mathrm{~mm} \mathrm{Hg}$ vacuum. Filters were placed in scintillation vials with $1 \mathrm{ml}$ of acidified methanol ( $5 \%$ glacial acetic acid) to remove the residual inorganic ${ }^{14} \mathrm{C}$ and evaporated to dryness. Prior to liquid scintillation counting, the vial contents were resuspended in $1.5 \mathrm{ml}$ distilled water followed by $15 \mathrm{ml}$ scintillation fluid (Optiphase Hi-Safe II, Wallac UK Ltd).

The rate of carbon uptake by single or small numbers of heterotrophic dinoflagellate cells $\left(q_{3}\right)$ was determined by liquid scintillation counting using a technique described by Rivkin \& Seliger (1981). Aliquots of the incubated sample were gently concentrated by reverse filtration onto a $10 \mu \mathrm{m}$ aperture mesh, rinsed with GF/F filtered sea water from the $10 \mathrm{l}$ aspirator and transferred in a drop of water to a cooled microscope slide. Dinoflagellate cells were isolated from each sample within $1 \mathrm{~h}$ following reverse filtration. A micro-manipulation system attached to a Wild M40 inverted microscope was used to isolate specific dinoflagellate cells and to transfer them through 2 washes of filtered sea water. From the final wash between 1 and 35 cells were transferred in a volume of less than $5 \mu \mathrm{l}$ to a $5 \mathrm{ml}$ plastic insert vial. To avoid cell damage, precautions were taken to minimise temperature and osmotic change during sample manipulation. To control for the inadvertent transfer of organic ${ }^{14} \mathrm{C}$ not incorporated by heterotrophic dinoflagellates, a control vial was prepared incorporating an equal volume of the final wash used to prepare each experimental vial. $250 \mu \mathrm{l}$ of acidified methanol (5\% glacial acetic acid) was then added to each vial and evaporated to dryness to remove inorganic ${ }^{14} \mathrm{C}$. Prior to liquid scintillation counting $0.5 \mathrm{ml}$ of distilled water was added to each vial followed by $4.0 \mathrm{ml}$ of scintillation fluid.

Radiocarbon activity in the dinoflagellate cells was relatively low and therefore a number of measures were taken to increase the sensitivity of standard liquid scintillation counting techniques. The 'critical' counting rate below which no radioisotope activity can be quantified by liquid scintillation counting is related to counting time and the levels of background count (Simonnet 1990). Precautions to minimise the background count included the use of both plastic insert and outer vials, low volumes of scintillation fluid and efforts to minimise static electricity. Respective control vials were counted between each sample and to the same accuracy of less than or equal to $5 \%$ error, resulting in counting times of between 45 and $300 \mathrm{~min}$. Counting efficiency was calculated by external standard spectrum analysis calibrated with similar plastic vials and content volumes to the experimental samples.

Preliminary experiments in which control incubations were conducted using formalin poisoned samples or darkened incubation bottles (Montagna 1984) produced levels of radioisotope activity in the heterotrophic dinoflagellates that were below the critical level of detection. Therefore, poisoned or dark incubations were not carried out in parallel with experimental incubations. Instead, any inorganic ${ }^{14} \mathrm{C}$ transferred into the scintillation vials along with the heterotrophic dinoflagellates or final wash was assumed to have been removed prior to liquid scintillation counting by the addition of the acid. In addition, any errors related to the transfer of organic ${ }^{14} \mathrm{C}$ not incorporated in heterotrophic dinoflagellate cells were accounted for by the use of control vials containing equal quantities of the final wash in each case.

In order to verify the linear incorporation of radioisotope by the phytoplankton, as assumed by Daro's (1978) model, a time series control experiment was conducted in which the uptake of ${ }^{14} \mathrm{C}$ was measured over a $9 \mathrm{~h}$ period in 3 replicate water samples incubated simultaneously. 
Data analyses. For each experiment, clearance and ingestion rate for each dinoflagellate taxon was calculated from the measured activity $(\mathrm{dpm})$ of ${ }^{14} \mathrm{C}$ in particulate matter $\left(q_{2}\right)$ and heterotrophic dinoflagellates $\left(q_{3}\right)$. Clearance rates ( $\mu$ cell $\mathrm{cel}^{-1} \mathrm{~h}^{-1}$ ) were calculated from $q_{2}$ values normalised to water volume $\left(\mathrm{dpm} \mathrm{Ll}^{-1}\right)$ and

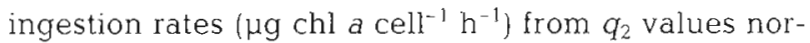
malised to $\mathrm{chl}$ a concentration [dpm ( $\mu \mathrm{g}$ chl $\left.a)^{-1}\right]$. On each occasion the ${ }^{14} \mathrm{C}$ concentration in the grazers, $q_{3}$ $(\mathrm{dpm})$, was calculated from the activity measured in the sample vial minus the activity of the respective control vial. The critical level of detection (DL) is given by the relation:

$$
D L=2 \sqrt{(2 n / t)}
$$

where $n$ is the background in dpm, and $t$ is the counting time in minutes (Simonnet 1990). Only values of $q_{3}$ exceeding the detection limit after a counting time of $\leq 300$ min were used to calculate clearance and ingestion rates.

Mean taxon-specific cellular clearance and ingestion rates were calculated from pooled experimental results and were used to calculate population grazing rates on the 8 occasions when dinoflagellate abundance was determined. These values are used to compute the proportion of the water column cleared, phytoplankton biomass ingested and primary production consumed by the heterotrophic dinoflagellates on each sampling date.

\section{RESULTS}

\section{Environment}

Break out of fast ice on 23 December 1993 in the vicinity of Davis station coincided with increased water temperatures and preceded a change in the compasition and biomass of the autotrophic commu- nity in the water column. The present study covered a period of almost a month, from 14 January to 11 February 1994, and coincided with the development and subsequent decline of a diatom-dominated bloom in coastal waters. The major component of the phytoplankton was the centric diatom Actinocyclus sp. whilst the diatoms Asteromphalus sp., Chaetoceros spp., Coscinodiscus spp. and Thalassiosira spp., and a small Cryptomonas sp., were also prominent. Chl a concentrations in the experimental samples peaked between 25 January and 2 February reaching a maximum of $20.7 \mathrm{\mu g} \mathrm{l}^{-1}$ and values declined rapidly thereafter to $1.9 \mathrm{Hg} \mathrm{l}^{-1}$ on 11 February (Fig. 2, Table 1). Although near-shore water temperatures increased during the summer months, temperature remained below $-0.4^{\circ} \mathrm{C}$ during the study and declined to $-1.4^{\circ} \mathrm{C}$ by 11 February (Fig. 2)

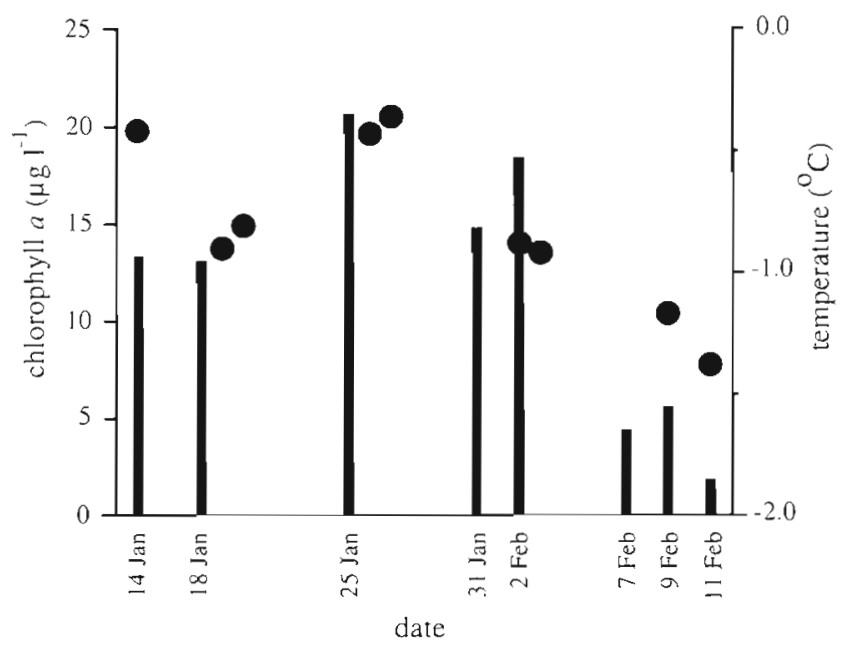

Fig. 2. Chlorophyil a concentration (bars) and water temperature (1) measured at $5 \mathrm{~m}$ depth at the fixed sampling site at O'Gorman Rocks during the study period in summer 1993-94

Table 1. Sampling dates, total abundance and biomass of the isolated heterotrophic dinoflagellate population and chlorophyll a (chl a) concentration ( $\pm S D, n=3$ ) at $5 \mathrm{~m}$ depth at $\mathrm{O}^{\prime}$ Gorman Rocks during the austral summer 1993-94. To estimate the relative proportion of the biomass of heterotrophic dinoflagellates to autotrophs, autotrophic biomass was calculated using a carbon chl a ratio of 46 (Hewes et al. 1990) and heterotrophic dinoflagellate biomass from $140 \mathrm{fg} \mathrm{C} \mathrm{mm}^{-3}$ cell volume (as quoted in Lessard 1991)

\begin{tabular}{|c|c|c|c|c|}
\hline \multirow[t]{2}{*}{ Date of sampling } & \multicolumn{2}{|c|}{ Heterotrophic dinoflagellate } & \multirow{2}{*}{$\begin{array}{c}\text { Chl a } \\
\left(\operatorname{lg~l}^{-1}\right)\end{array}$} & \multirow{2}{*}{$\begin{array}{l}\text { Proportion of dinoflagellate: } \\
\text { autotrophic biomass }(\%)\end{array}$} \\
\hline & Abundance (cells $\times 10^{3} \mathrm{I}^{-1}$ ) & Biomass ( $\mu \mathrm{g} \mathrm{Cl}^{-1}$ ) & & \\
\hline 14 Jan & 4.5 & 10.6 & $13.4 \pm 2.2$ & 1.7 \\
\hline $18 \mathrm{Jan}$ & 7.4 & 21.5 & $13.1 \pm 0.2$ & 3.6 \\
\hline $25 \mathrm{Jan}$ & 21.9 & 50.2 & $20.7 \pm 0.5$ & 5.3 \\
\hline $31 \mathrm{Jan}$ & 44.6 & 114.5 & $14.8 \pm 0.6$ & 16.8 \\
\hline 2 Feb & 29.0 & 64.9 & $18.4 \pm 0.5$ & 7.7 \\
\hline $7 \mathrm{Feb}$ & 33.6 & 81.2 & $4.4 \pm 0.2$ & 39.8 \\
\hline 9 Feb & 32.1 & 74.3 & $5.6 \pm 0.3$ & 28.8 \\
\hline 11 Feb & 16.8 & 40.0 & $1.9 \pm 0.1$ & 46.0 \\
\hline
\end{tabular}




\section{Species descriptions}

A diverse and abundant dinoflagellate population occurred during the summer phytoplankton bloom and the high abundance of large heterotrophic forms was a prominent feature in the plankton. Nine dinoflagellate taxa were identified and selected for grazing rate measurements, including 2 naked and 7 armoured taxa (Table 2).

Cell volumes and linear dimensions of material fixed in $1 \%$ Lugol's iodine are given for each taxon in Table 2. Gyrodinium sp. 1 was the smaller of the 2 naked taxa.
When live, this species was flexible and able to change cell shape rapidly. Under blue light illumination Gyrodinium sp.1 fluoresced green and some fixed specimens were observed in the process of ingesting (Fig. 3) or contained previously ingested centric diatom cells. In contrast, the larger Gyrodinium sp.2 fluoresced yellow/green under blue light and no specimens were observed to have ingested diatom cells. Scanning electron microscopy illustrated the striations on the cell surface of both species of Gyrodinium. In each case the striations on the hypocone were narrower and more abundant than on the epicone (Fig. 3).

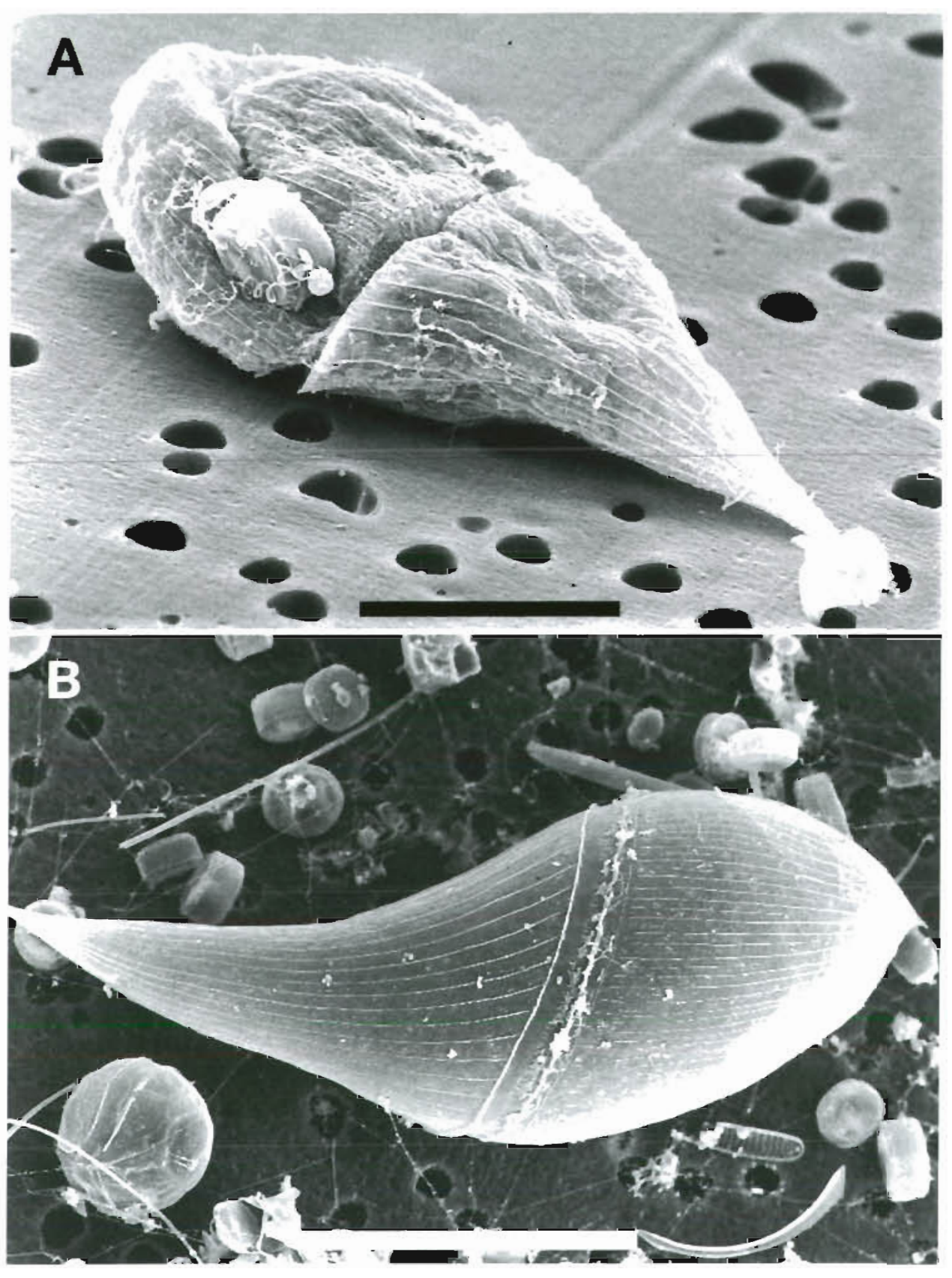

Fig. 3. SEM micrographs of the 2 naked heterotrophic dinoflagellate taxa selected for grazing rate measurements: (A) Gyrodinium sp.1 in the process of ingesting a centric diatom through the sulcus (scale bar $=20 \mu \mathrm{m}$ ), (B) the larger but less abundant Gyrodinium sp.2 (scale bar $=50 \mu \mathrm{m}$ ) 
Table 2. Details of the heterotrophic dinoflagellate species for which measurements of grazing rates were obtained. Mean cell breadth (with range) and mean cell volume (with upper and lower standard deviation) were calculated from log $10^{-t r a n s f o r m e d ~ v a l u e s . ~}$ The range of abundance and biomass of each taxon was measured during the sampling period from 14 January to 11 February

\begin{tabular}{|lcccc|}
\hline Taxon & $\begin{array}{c}\text { Cell breadth } \\
(\mu \mathrm{m})\end{array}$ & $\begin{array}{c}\text { Cell volume } \\
\left(\times 10^{3} \mu \mathrm{m}^{3}\right)\end{array}$ & $\begin{array}{c}\text { Range of abundance } \\
\left.(\text { cells })^{-1}\right)\end{array}$ & $\begin{array}{c}\text { Range of biomass } \\
\left(\mu \mathrm{C} \mathrm{I}^{-1}\right)\end{array}$ \\
\hline Gyrodinium sp.1 & $64(36-90)^{\mathrm{a}}$ & $12.5(5.8 / 10.7)$ & $2000-19500$ & $3.5-34.2$ \\
Gyrodinium sp.2 & $119(74-163)^{\mathrm{d}}$ & $59.5(22.2 / 35.5)$ & $200-6200$ & $1.3-53.8$ \\
Diplopeltopsis spp. & $24(20-28)$ & $5.4(1.4 / 1.9)$ & $1500-16100$ & $1.1-12.1$ \\
Protoperidinium cf. applanatum (Manguin) Balech & $36(22-50)$ & $13.4(5.4 / 9.0)$ & $400-1100$ & $0.4-2.3$ \\
Protoperidinum sp.1 & $48(34-61)$ & $31.8(7.2 / 9.3)$ & $100-1100$ & $0.5-4.5$ \\
Protoperidinum sp.2 & $50(33-77)$ & $30.4(10.5 / 16.1)$ & $80-680$ & $0.3-2.9$ \\
Protoperidinium sp.3 & $56(45-69)$ & $62.9(12.7 / 15.9)$ & $20-220$ & $0.2-4.4$ \\
P. cf. pseudoantarcticum (Balech) Balech & $58(39-85)$ & $61.3(24.4 / 40.6)$ & $40-260$ & $0.6-2.2$ \\
P. antarcticum (Schimper) Balech & $123(110-139)$ & $332.4(58.2 / 70.5)$ & $20-90$ & $0.9-4.2$ \\
aFor naked taxa mean cell length rather than breadth is given & & & & \\
& & & & \\
\end{tabular}

The armoured dinoflagellates ranged in size from the small Diplopeltopsis spp. to the largest of Antarctic dinoflagellates, Protoperidinium antarcticum (Schimper) Balech (Table 2). Diplopeltopsis spp. had a lenticular shape with a shallow cingulum and reduced or absent antapical and apical spines. P. cf. applanatum (Mangin) Balech was characterised by widely spaced long antapical spines, a relatively small and wide body and a steep apical horn. Protoperidinium sp.1 had a generally larger more robust body, with double or false antapical spines. Protoperidinium sp. 2 was recognised by the flattened 'ovatum' form and possessed antapical spines and an apical horn. Protoperidinium sp. 3 was a relatively large robust form with no spines or horns present, narrow cingular lists and darkly staining protoplasm. $P$. antarcticum was easily distinguished by its size and large antapical horns, one of which is shorter and curled towards the other. $P$. cf. pseudoantarcticum (Balech) Balech was smaller but similar in appearance to $P$. antarcticum with relatively long antapical horns. All the armoured dinoflagellates fluoresced green under blue light except $P$. cf. applanatum which fluoresced yellow/green.

\section{Abundance and biomass of the heterotrophic dinoflagellates}

All 9 taxa of heterotrophic dinoflagellate selected for grazing rate measurements showed an increase in abundance during the phytoplankton bloom (Fig. 4). The 2 most abundant taxa were the armoured Diplopeltopsis spp. and the naked Gyrodinium sp.1, reaching maximum values of 16100 and 19500 cells $l^{-1}$ and 12.1 and $34.3 \mu \mathrm{g} \mathrm{C}^{-1}$ respectively (Table 2, Fig. 4). Gyrodinium sp.2 also reached high abundance with 6200 cells $\mathrm{l}^{-1}$ making up a maximum taxon-specific

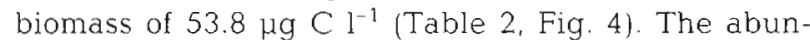

dances of the remainder of the armoured taxa were considerably lower with individual taxa rarely exceed-

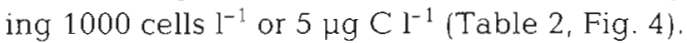

The 9 taxa used for experiments comprised up to $85 \%$ of the heterotrophic dinoflagellate cells of greater than $10 \mu \mathrm{m}$ in size. It proved impossible to isolate all the heterotrophic taxa because of their low abundance, fragility or small size. Therefore, the values of total abundance and biomass of the heterotrophic dinoflagellate population given in this study are minimum values and include only those taxa selected for grazing rate measurements.

The total abundance and biomass of the heterotrophic dinoflagellate population increased exponentially from 14 January to reach a maximum abundance,

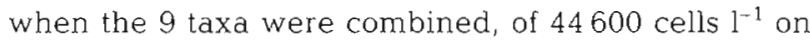
31 January, equivalent to a standing stock of $114.5 \mu \mathrm{g}$ $\mathrm{C}^{-1}$ (Table 1, Fig 4). The relative proportion of heterotrophic dinoflagellate to autotrophic biomass increased during the study period, and when a C:chl a ratio of 46 is used (Hewes et al. 1990), equalled a maximum of $46 \%$ of autotrophic biomass by 11 February (Table 1).

\section{Grazing rate measurements}

Daro's (1978) model assumes that the concentration. of ${ }^{14} \mathrm{C}$ in the water $\left(q_{1}\right)$ remains high relative to the autotrophic and heterotrophic compartments and that the uptake of ${ }^{14} \mathrm{C}$ by phytoplankton $\left(q_{2}\right)$ is linear over the duration of the experimental incubations. ${ }^{14} \mathrm{C}$ activity measured in the experimental samples at the beginning of incubations and in $2.0 \mu \mathrm{m}$ filtered water at the end indicated a negligible reduction in the level of $q_{1}$. In addition, the incorporation of ${ }^{14} \mathrm{C}$ in particulate matter in 3 replicate incubations over a $9 \mathrm{~h}$ period was essentially linear $\left[\mathrm{dpm}=108.4(\mathrm{~h})-32.1, \mathrm{r}^{2}=0.97\right]$, and 

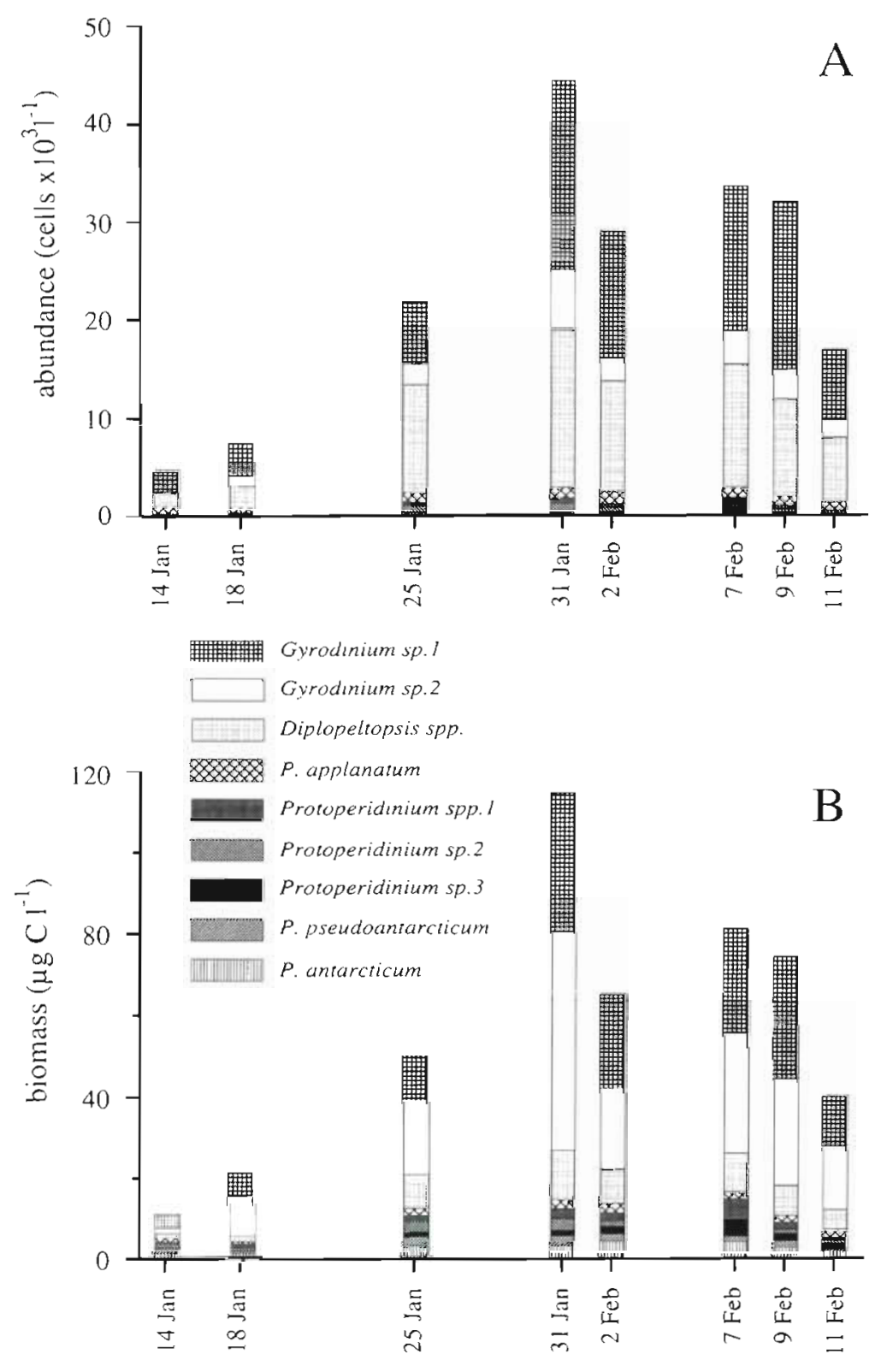

date

Fig. 4. Total (A) abundance and (B) biomass of the heterotrophic dinoflagellate population measured in water samples collected at $5 \mathrm{~m}$ depth at $\mathrm{O}^{\prime} \mathrm{Gor}$ man Rocks during the study period in summer 1993-94. Values represent the combined abundance and biomass of the 9 taxa of heterotrophic dinoflagellate selected for grazing rate measurements

therefore verified the assumption of linear uptake by phytoplankton $\left(q_{2}\right)$.

The number of experiments in which a grazing rate was successfully measured for each taxon ranged from 14 out of 16 experiments for Diplopeltopsis spp. to 4 out of 6 for Protoperidinium sp.3. Taxon abundance was the major factor that contributed to this variability as the most abundant taxa were the easiest to isolate in suffi- cient numbers during the post-incubation processing period. One consequence of the methodological approach, which arises from the low number of cells that can be isolated during each experiment, appears to be high variability in the measurement of taxon-specific grazing rate between experimental samples (Table 3). This high variability should be taken into account when considering the following estimates of mean grazing and growth rates.

Mean taxon-specific clearance rates varied by more than 10 -fold from $0.028 \mu \mathrm{cell}^{-1} \mathrm{~h}^{-1}$ in Diplopeltopsis spp. to $0.318 \mu \mathrm{cell}^{-1} \mathrm{~h}^{-1}$ in Protoperidinium sp.3 (Table 3). In contrast, mean taxonspecific rates of ingestion varied only 3 -fold from $0.72 \mathrm{pg}$ chl a cell ${ }^{-1} \mathrm{~h}^{-1}$ in Diplopeltopsis spp. to $2.38 \mathrm{pg}$ chl a cell ${ }^{-1}$ $\mathrm{h}^{-1}$ in Protoperidinium sp.3 (Table 3). Mean volume-specific clearance rates were inversely related to cell volume with the highest value of $5210 \mathrm{~h}^{-1}$ measured in Diplopeltopsis spp. and the lowest of $810 \mathrm{~h}^{-1}$ measured in $P$. antarcticum (Table 4). Clearance and ingestion rates were similar between naked and armoured taxa of similar size. The rate of ingestion of carbon biomass (pg $\mathrm{C}$ cell-1 $\mathrm{h}^{-1}$ ) and carbon-specific ingestion rates $\left(\mathrm{h}^{-1}\right)$ can be calculated from the mean ingestion rates (pg chl a cell ${ }^{-1} \mathrm{~h}^{-1}$ ) for each taxon of heterotrophic dinoflagellates (Table 4). Estimated carbon-specific ingestion rates were inversely related to cell volume, ranging from $0.002 \mathrm{~h}^{-1}$ in $P$. antarcticum to $0.023 \mathrm{~h}^{-1}$ in Diplopeltopsis spp. (Table 4, Fig. 5).

During the period from 14 January to 11 February the mean population grazing rates of the 2 Gyrodinium species and Diplopeltopsis spp. were an order of magnitude higher than those calculated for the other heterotrophic dinoflagellates (Table 3). The combined grazing rates of the 9 heterotrophic dinoflagellate taxa increased exponentially to a maximum value on 31 January (Fig. 6) which coincided with the highest observed heterotrophic dinoflagellate abundance and biomass (Fig. 4) and followed approximately $6 \mathrm{~d}$ after the maximum recorded chl a values (Fig. 2). Total ingestion rate of the 9 taxa was $29.7 \mathrm{ng}$ chl a $\mathrm{l}^{-1} \mathrm{~h}^{-1}$ on 31 January, of which $92 \%$ was consumed by the 3 most abundant species, Gyrodinium sp.1, Gyrodinium sp.2 and Diplopeltopsis spp. (Fig. 6). 
Table 3. Taxon-specific grazing rates of heterotrophic dinoflagellates on autotrophic production in Antarctic coastal waters. Clearance and ingestion rates were calculated from counts of ${ }^{14} \mathrm{C}$ activity in heterotrophic dinoflagellates $\left(q_{3}\right)$ above the 'critical' detection level ( $>\mathrm{DL}$, see text for details). To calculate clearance and ingestion rates, ${ }^{14} \mathrm{C}$ incorporation in particulate matter $\left(q_{2}\right)$ was normalised to water volume $\left(\mathrm{dpm} \mu \mathrm{l}^{-1}\right)$ and $\mathrm{chl}$ a concentration $\left[\mathrm{dpm}(\mu \mathrm{g} \mathrm{chl} \mathrm{a})^{-1}\right]$ respectively. For each taxon. values are the mean $\pm \mathrm{SD}$ of the experiments in which a grazing rate was measured. The mean taxon-specific population clearance and ingestion rates were calculated from 8 sampling dates over the period 14 January to 11 February

\begin{tabular}{|c|c|c|c|c|c|c|}
\hline Taxon & $\begin{array}{l}\text { Proportion } \\
\text { of counts } \\
>D L\end{array}$ & $\begin{array}{l}\text { No. of cells } \\
\text { per vial }\end{array}$ & $\begin{array}{l}\text { Clearance rate } \\
\left(\mu I \text { cell }^{-1} \mathrm{~h}^{-1}\right)\end{array}$ & $\begin{array}{l}\text { Ingestion rate } \\
\left.\text { (pg chl a cell } h^{-1}\right)\end{array}$ & $\begin{array}{l}\text { Mean population } \\
\text { clearance rate } \\
\left(\mu \mathrm{l}^{-1} \mathrm{~h}^{-1}\right)\end{array}$ & $\begin{array}{l}\text { Mean population } \\
\text { ingestion rate } \\
\text { (ng chl } a l^{-1} h^{-1} \text { ) }\end{array}$ \\
\hline Gyrodinium sp. 1 & $10 / 11$ & $3-17$ & $0.063 \pm 0.05$ & $0.717 \pm 0.30$ & 0.66 & 7.5 \\
\hline Gyrodinium sp.2 & $7 / 10$ & $3-10$ & $0.146 \pm 0.19$ & $1.161 \pm 0.50$ & 0.37 & 3.0 \\
\hline Diplopeltopsis spp. & $14 / 16$ & $12-35$ & $0.028 \pm 0.01$ & $0.376 \pm 0.27$ & 0.25 & 3.3 \\
\hline Protoperidinium cf applanatum & $m \quad 6 / 10$ & $4-25$ & $0.031 \pm 0.015$ & $0.409 \pm 0.34$ & 0.02 & 0.3 \\
\hline Protoperidinium sp. 1 & $5 / 5$ & $3-11$ & $0.075 \pm 0.06$ & $1.242 \pm 1.00$ & 0.03 & 0.5 \\
\hline Protoperidinium sp.2 & $4 / 5$ & $6-10$ & $0.051 \pm 0.05$ & $0.805 \pm 1.05$ & 0.02 & 0.2 \\
\hline Protoperidinium sp.3 & $4 / 6$ & $3-12$ & $0.318 \pm 0.32$ & $2.383 \pm 2.84$ & 0.05 & 0.4 \\
\hline P. cf pseudoantarcticum & $5 / 8$ & $1-20$ & $0.101 \pm 0.05$ & $0.890 \pm 0.62$ & 0.02 & 0.1 \\
\hline P. antarcticum & $5 / 6$ & 1 & $0.269 \pm 0.20$ & $2.183 \pm 1.29$ & 0.05 & 0.1 \\
\hline
\end{tabular}

Table 4. Estimation of the taxon-specific rates of volume-specific clearance, carbon ingestion, carbon-specific ingestion and specific growth. Volume-specific clearance rates were calculated from measured cell volume (Table 1) and cell clearance rates (Table 3). Carbon-specific ingestion rates were calculated from carbon per heterotrophic dinoflagellate cell $\left(140 \mathrm{fg}^{\mathrm{C}} \mu \mathrm{m}^{-3}\right.$, as quoted in Lessard 1991) and carbon ingestion rates (Table 3) assuming an autotrophic carbon:chl a ratio of 46 (Hewes et al. 1990). Specific growth rates were calculated assuming a 0.40 gross growth efficiency for heterotrophic dinoflagellate cells feeding on phytoplankton (see text for details)

\begin{tabular}{|lcccc|}
\hline Taxon & $\begin{array}{c}\text { Volume-specific } \\
\text { clearance }\left(\mathrm{h}^{-1}\right)\end{array}$ & $\begin{array}{c}\text { Ingestion rate } \\
\left(\mathrm{pgCc} \mathrm{pell}^{-1} \mathrm{~h}^{-1}\right)\end{array}$ & $\begin{array}{c}\text { Specific ingestion } \\
\left(\mathrm{h}^{-1}\right)\end{array}$ & $\begin{array}{c}\text { Specific growth } \\
\left(\mu, \mathrm{d}^{-1}\right)\end{array}$ \\
\hline Gyrodinium sp.1 & 5020 & 33.0 & 0.019 & 0.125 \\
Gyrodinium sp.2 & 2450 & 53.4 & 0.006 & 0.041 \\
Diplopeltopsis spp. & 5210 & 17.3 & 0.023 & 0.150 \\
Protoperidinium cf. applanatum & 2280 & 18.8 & 0.009 & 0.062 \\
Protoperidinium sp.1 & 2360 & 57.1 & 0.013 & 0.085 \\
Protoperidinium sp.2 & 1680 & 37.0 & 0.009 & 0.058 \\
Protoperidinium sp.3 & 5050 & 109.6 & 0.012 & 0.067 \\
P. cf. pseudoantarcticum & 1650 & 40.9 & 0.005 & 0.032 \\
P. antarcticum & 810 & 100.4 & 0.002 & 0.014 \\
\hline
\end{tabular}

Daily population clearance and ingestion rates were calculated from the experimentally derived hourly rates, assuming constant grazing throughout the day. The total clearance rate of the 9 dinoflagellate taxa represented between 0.6 and $6.7 \%$ of the water column per day during the study period (Table 5). A value of 46 for the ratio of autotrophic carbon:chl a (Hewes et al. 1990) can be used to estimate the amount of carbon consumed ( $\mu \mathrm{g} \mathrm{C} \mathrm{l}^{-1} \mathrm{~d}^{-1}$ ) from measured ingestion rates ( $\mu \mathrm{g}$ chl $\mathrm{a} \mathrm{l}^{-1} \mathrm{~h}^{-1}$ ). Estimates of total ingestion by the 9 taxa reached maximum values of over $10 \%$ of the total autotrophic biomass consumed per day during the decline of the phytoplankton bloom (Table 5). Furthermore, the impact of grazing by heterotrophic dinoflagellates on primary production can be estimated from ingestion rates measured in the present study and daily rates of phytoplankton ${ }^{14} \mathrm{C}$ incorporation measured concurrently by Robinson et al. (unpubl.). The proportion of daily primary production ingested per day by the 9 dinoflagellate taxa increased during the study period from $1.5 \%$ on 14 January to over $20 \%$ during the later stages of the phytoplankton bloom (Table 5).

\section{DISCUSSION}

The present study provides invaluable information on taxon-specific cellular and population grazing rates of heterotrophic dinoflagellates and the potential grazing impact of the combined dinoflagellate population, during a summer phytoplankton bloom in the Antarc- 


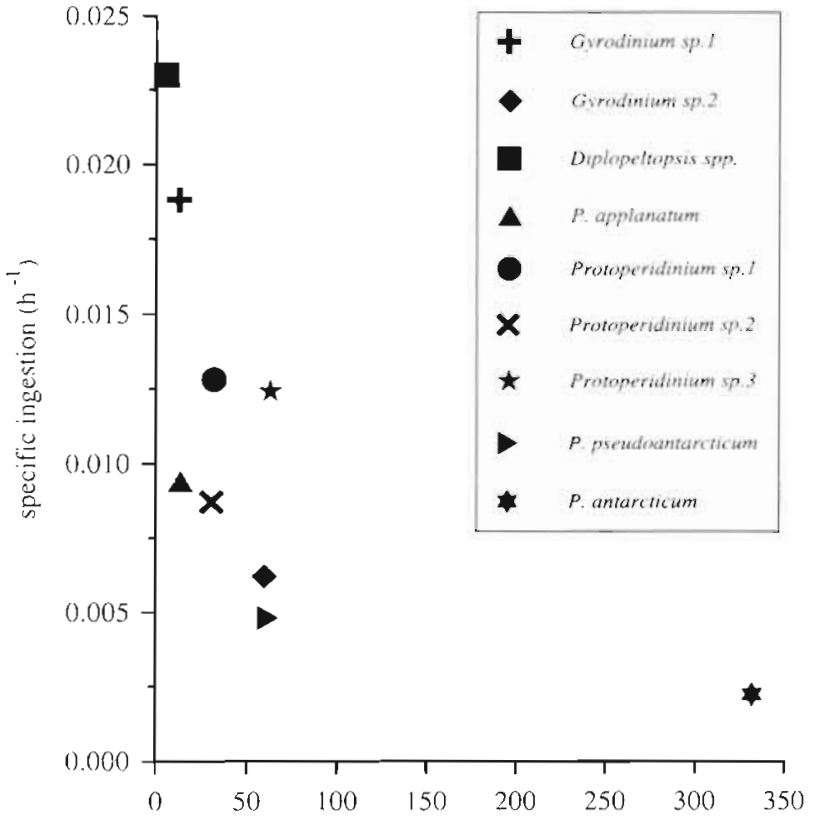

Fig. 5. Carbon-specific ingestion rates as a function of cell volume for the 9 heterotrophic dinoflagellate taxa selected for grazing rate measurements

tic. However, before discussing the significance of the results it is pertinent to consider the methods that were used.

\section{Methodology}

Daro's (1978) model assumes that the uptake of radioisotope by the phytoplankton is linear over time, that the concentration of ${ }^{14} \mathrm{C}$ remains high in the water compared to that in the phytoplankton and dinoflagellates and that no recycling of ${ }^{14} \mathrm{C}$ occurs within the system. As stated in the 'Results', both the assumptions of linear uptake in $q_{2}$ and high and stable concentrations of isotope in the water $\left\{q_{1}\right\}$ were verified in the present study. However, to limit the extent of recycling of the radioisotope tracer the duration of experiments should ideally be kept to a minimum. In the present study it was necessary to run incubations for between 6 and $9 \mathrm{~h}$ because the incorporation rate of ${ }^{14} \mathrm{C}$ by heterotrophic dinoflagellates was relatively slow and only a small number of cells of individual taxa could be isolated from the experimental samples during the processing time. Therefore, there is a possibility that the experimental procedures used resulted in some recycling of ${ }^{14} \mathrm{C}$ within the system and the likelihood and implications of this are now discussed.

The degree of recycling of ${ }^{14} \mathrm{C}$ that took place during the incubations would be a product of respiratory and excretory losses from both autotrophic and heterotrophic compartments. The respiratory loss of ${ }^{14} \mathrm{C}$ from autotrophs would depend on the extent to which recently incorporated ${ }^{14} \mathrm{C}$ enters the respiratory substrate pool(s) during incubation. However, the interpretation of ${ }^{14} \mathrm{C}$ measurements of phytoplankton production is limited by a lack of understanding of algal respiration (Williams 1993). In the context of the present study the incorporation of ${ }^{14} \mathrm{C}$ in the phytoplankton greater than $2.0 \mu \mathrm{m}$ was essentially linear (Fig 5) and therefore any respiratory loss of ${ }^{14} \mathrm{C}$ was either constant or very low and is not expected to prejudice the calculations of grazing rate.

It is possible that grazing rates could have been underestimated due to losses during egestion, respiration and excretion of ${ }^{14} \mathrm{C}$ by the heterotrophs. As for autotrophs, the loss of incorporated ${ }^{14} \mathrm{C}$ in heterotrophs would depend on the rate at which recently incorporated ${ }^{14} \mathrm{C}$ entered the respiratory substrate pool(s). The loss of ${ }^{14} \mathrm{C}$ from the cells of grazers would be dependent in part on food processing times. Het-

Table 5. Grazing impact by the isolated heterotrophic dinoflagellate population on daily primary production during a summer phytoplankton bloom at a coastal Antarctic site. Calculation of the percentage of total primary production consumed is based upon ${ }^{14} \mathrm{C}$ production data measured in water samples from $5 \mathrm{~m}$ depth at O'Gorman Rocks at biweekly intervals during the summer (Robinson et al. unpubl.)

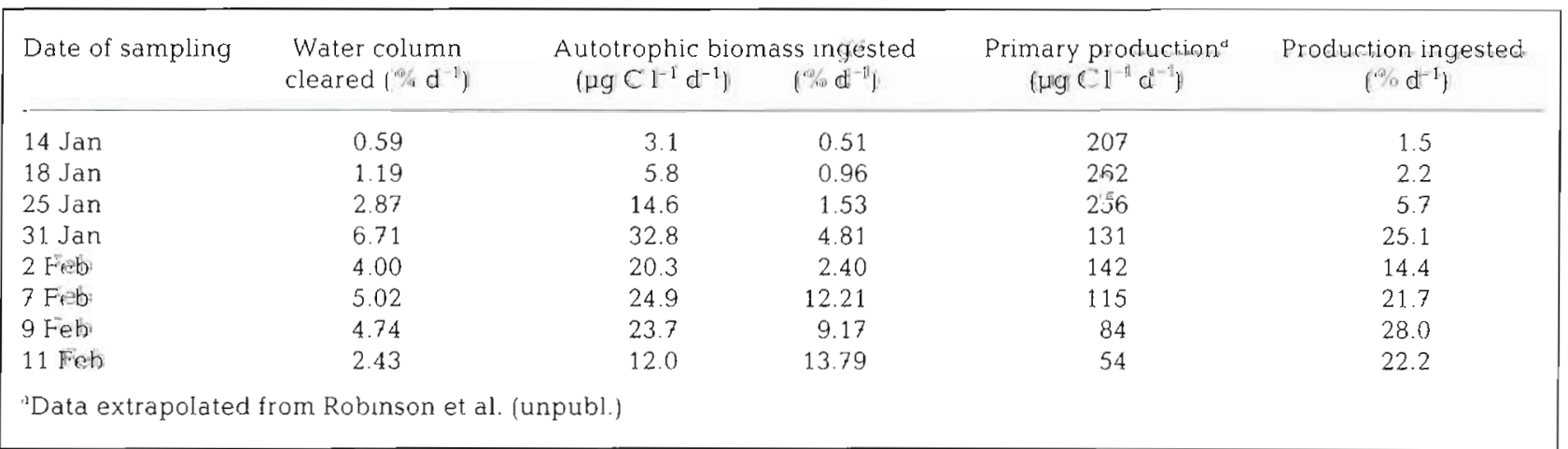


erotrophic dinoflagellate species exhibit a variety of feeding methods involving intracellular or 'extrasomal' digestion of prey and there is evidence to suggest that the food processing time differs with feeding method (Elbrächter 1991). Reported food processing times for phagotrophic species span many hours. For instance, the mixotrophic Gymnodinium sanguineum digested ciliates at a rate of $23 \% \mathrm{~h}^{-1}$ (Bockstahler \& Coats 1993) and digestion of Dunaliella primolecta by Oxyrrhis marina takes 12 to 24 h lÖpik \& Flynn 1989). In contrast, observations of the duration of pallium feeding by dinoflagellates suggest that they are attached to their prey for relatively short periods of time of generally less than an hour (Jacobson \& Anderson 1993, Strom \& Buskey 1993, Jeong \& Latz 1994). Therefore, the rate of loss or recycling of ${ }^{14} \mathrm{C}$ from the grazers may vary between taxa that employ different feeding modes. However, the phytoplankton that were consumed at an early stage of the incubations, and were therefore digested and/or egested first, would have a lower ${ }^{14} \mathrm{C}$ content than prey consumed at a later stage. This reduces the potential bias in the measurements of grazing rate due to recycling or loss of ${ }^{14} \mathrm{C}$ from the heterotrophic compartment (Daro \& Baars 1986). Continuing this theme, the method used to obtain grazing rates in the present study is potentially biased towards measuring higher rates in species that feed phagotrophically or by myzocytosis and therefore possibly contained undigested ${ }^{14} \mathrm{C}$-labelled phytoplankton material, compared to taxa that use a pallium and transport only digested material into the cell body.

Several other experimental procedures may also have influenced the grazing rate measurements of the present study. The values used for the amount of ${ }^{14} \mathrm{C}$ incorporated in the autotrophic compartment $\left(q_{2}\right)$ were measurements of ${ }^{14} \mathrm{C}$ content in particulate matter filtered onto $2.0 \mu \mathrm{m}$ filters. Therefore $q_{2}$ values did not include the photosynthetic incorporation of ${ }^{14} \mathrm{C}$ in particulate matter of less than $2.0 \mu \mathrm{m}$ or in ${ }^{14} \mathrm{C}$ excreted as dissolved organic matter, which made up approximately 5 and $10 \%$, respectively, of the photosynthetically incorporated ${ }^{14} \mathrm{C}$ in size fractionated samples from $24 \mathrm{~h}$ incubations (Robinson et al. unpubl.). As a result, the clearance and ingestion rates given in the present study may lead to a slight overestimate of the grazing impact on total photosynthetic production (Table 5). Further, the dissolved organic matter excreted by phytoplankton may be incorporated by bacteria and bacterial incorporation of ${ }^{14} \mathrm{C}$-labelled organic matter may have affected the estimates of grazing rate by recycling of the tracer.

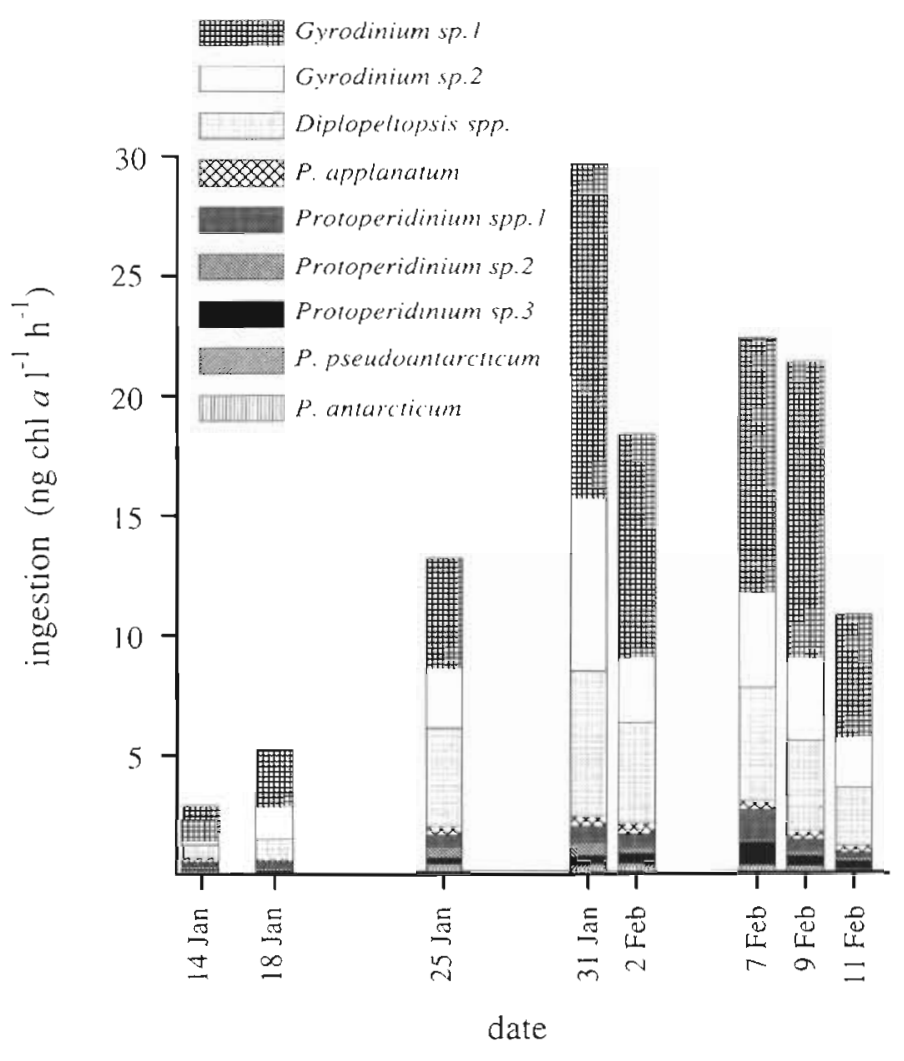

Fig. 6. Estimates of the total combined ingestion rates of the 9 taxa of heterotrophic dinoflagellate measured in water samples col lected at $5 \mathrm{~m}$ depth at $\mathrm{O}^{\prime}$ Gorman Rocks durnng the study period

Another discrepancy in grazing rate measurements may have arisen if the grazers were size-selective feeders, due to any disproportionate uptake of ${ }^{14} \mathrm{C}$ by different-sized phytoplankton (Tackx \& Daro 1993). This discrepancy was shown to be of least significance if the bulk of the phytoplankton biomass is concentrated in a narrow size range (Tackx \& Daro 1993). During the present study the $>18 \mathrm{~m}$ size fraction contributed approximately $80 \%$ of ${ }^{14} \mathrm{C}$ incorporation (Robinson et al. unpubl.). Gyrodinium sp. 1 was able to ingest Actinocyclus sp. cells (Fig 3) and Protoperidinium applanatum was observed with captured Actinocyclus sp. cells, suggesting that these 2 species at least were feeding on the dominant phytoplankton size class.

Heterotrophic dinoflagellates are known to feed on a wide range of food items including bacteria, flagellates, diatoms, ciliates, other dinoflagellates and small metazoans (Lessard 1991). Therefore, there is a possibility that the ${ }^{14} \mathrm{C}$ accumulated by certain taxa examined in the present study was not derived directly from phytoplankton. Indeed, experiments in which ingestion of bacteria was estimated from the incorporation of ${ }^{3} \mathrm{H}$-thymidine derived from labelled bacteria suggest that bacteria may form a substantial part of the diet of 
pelagic dinoflagellates (Lessard \& Swift 1985, Lessard \& Rivkin 1986, Neuer \& Cowles 1995). However, recent evidence questions these findings as it has been shown that ${ }^{3} \mathrm{H}$-thymidine-labelled macromolecules derived from ${ }^{3} \mathrm{H}$-thymidine-labelled bacteria may be rapidly broken down by protists during digestion and do not accumulate within the predator (Zubkov \& Sleigh 1995). Furthermore, some dinoflagellates are mixotrophic and could directly incorporate inorganic ${ }^{14} \mathrm{C}$ which would result in an overestimate of grazing rates. However, the taxa for which grazing rates were obtained in the present study did not exhibit the bright red fluorescence associated with chloroplasts or the yellow-orange fluorescence that may be associated with autotrophic symbionts (Lessard \& Swift 1986, Bralewska \& Witek 1995).

Finally, when microscopy is used to determine the carbon biomass of microbial communities the accuracy of the final biomass estimate depends upon the determination of abundance, cell volumes and cell carbon:volume ratios. In this study, as with many others, the use of literature values to convert cell volume to carbon estimates is likely to introduce the

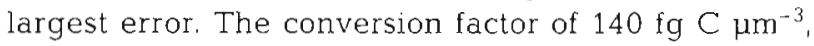
as quoted in Lessard (1991), is based on the carbon to cell volume of the small $(-20 \mu \mathrm{m}$ diameter $)$ heterotrophic armoured dinoflagellate Oblea rotunda (Strom \& Buskey 1993) and may not be ideal to use for larger armoured cells or naked dinoflagellates. There is obviously a need for further experimentally determined values of the carbon content of heterotrophic dinoflagellate cells. In addition, in the present study a fixed value for the autotrophic carbon to chl a ratio of 46 was used to estimate the autotrophic carbon content of sampled water from measured chl a concentrations. This value is the mean value of autotrophic carbon to chl a measured in water samples collected around the Southern Ocean and containing greater than $2.0 \mu \mathrm{g} \mathrm{chl} \mathrm{a} \mathrm{l}^{-1}$ (Hewes et al. 1990) and ignores the possibility of a non-linear relationship between autotrophic carbon and chl a concentrations.

\section{Grazing and growth rates}

Mean cell-specific clearance rates of heterotrophic dinoflagellates recorded in the present study were approximately an order of magnitude lower than values from the North Atlantic (Lessard \& Swift 1985) and off Oregon, USA (Neuer \& Cowles 1995) measured using similar radioisotope techniques. Clearance rates, which vary according to ambient food concentration, are likely to differ considerably between studies undertaken in different environments. In this respect, ingestion rates are a more useful means of comparing species in different environments. Unfortunately, ingestion rates cannot be calculated from the study by Lessard \& Swift (1985) or Neuer \& Cowles (1995). In addition, many heterotrophic dinoflagellates are now known to feed optimally on food of a similar size to themselves (Hansen 1992) and use of the less than $20 \mu \mathrm{m}$ size fraction of prey to calculate clearance rates in dinoflagellates of greater than $20 \mu \mathrm{m}$, as used by Lessard \& Swift (1985), may overestimate grazing rates on the phytoplankton community.

Mean taxon-specific gross growth efficiencies reported for marine heterotrophic dinoflagellates feeding on microalgae range from 0.60 in Oblea rotunda (Strom \& Buskey 1993) to 0.21 in Gymnodinium sp. (Strom 1991). Gross growth efficiencies are extremely sensitive to the conversion factors used in their calculation (Strom \& Buskey 1993). A mid-range value of 0.40 for the gross growth efficiency was used for all 9 taxa to calculate the specific growth rates from carbon-specific ingestion rates in the present study. The estimated specific growth rates ranged from $0.150 \mathrm{~d}^{-1}$ in Diplopeltopsis spp. to $0.014 \mathrm{~d}^{-1}$ in $P$. antarcticum (Table 4), corresponding to a doubling time of $4.6 \mathrm{~d}$ and $50 \mathrm{~d}$ respectively. When compared to studjes carried out in the laboratory (Table 6) the estimated specific ingestion and growth rates of Antarctic coastal dinoflagellates are low. Interestingly, the only study to give similar values for the growth and ingestion rates of heterotrophic dinoflagellates was undertaken in the Weddell Sea and Scotia-Weddell Confluence (Bjørnsen \& Kuparinen 1991). In microcosm experiments at $1^{\circ} \mathrm{C}$ the small heterotrophic dinoflagellate Gymnodinium sp. exhibited a maximal growth rate of $0.3 \mathrm{~d}^{-1}$, equivalent to a doubling time of $2.3 \mathrm{~d}$ (Bjørnsen \& Kuparinen 1991). Predator size and temperature are both important variables in the determination of protist ingestion rates (Peters 1994) and when these are taken into account the estimated ingestion and growth rates of the heterotrophic dinoflagellates in the present study are comparable to those measured by Bjørnsen \& Kuparinen (1991) for Gymnodinium sp.

The relatively low rates of ingestion and growth of heterotrophic dinoflagellates estimated from the present study and by Bjørnsen \& Kuparinen (1991) may be attributed to a number of factors. Single species of phytoplankton prey cultured in the laboratory may provide highly favourable growth conditions for the heterotrophic dinoflagellate concerned if the prey are of an optimum size and high nutritional value. Prey type has been shown to affect grazing and growth rates of heterotrophic dinoflagellates in a number of laboratory studies (Barlow et al. 1988, Goldman et al. 1989, Strom 1991, Hansen 1992, Strom \& Buskey 1993, 
Table 6. Comparative information on the maximum rates of ingestion and growth in marine, planktonic, heterotrophic dinoflagellates

\begin{tabular}{|c|c|c|c|c|c|c|c|}
\hline Predator & $\begin{array}{l}\text { Cell volume } \\
\qquad\left(\mathrm{\mu m}^{3}\right)\end{array}$ & Prey species & $\begin{array}{l}\text { Ingestion } \\
\quad(\mathrm{pg} \mathrm{C} \\
\left.\text { ind.-1 } \mathrm{h}^{-1}\right)\end{array}$ & $\begin{array}{c}\text { Specific } \\
\text { ingestion } \\
\left(\mathrm{h}^{-1}\right)\end{array}$ & $\begin{array}{c}\text { Specific } \\
\text { growth } \\
\left(d^{-1}\right)\end{array}$ & $\begin{array}{l}\text { Temperature } \\
\qquad\left({ }^{\circ} \mathrm{C}\right)\end{array}$ & Source \\
\hline \multicolumn{8}{|c|}{ Measurements from laboratory cultures } \\
\hline Oxyrrhis marina & $6300^{\circ}$ & $\begin{array}{l}\text { Phaeodactylum tricornutum } \\
\text { Isochrysis galbana }\end{array}$ & $\begin{array}{l}106 \text { to } \\
67\end{array}$ & $\begin{array}{l}0.141 \text { to } \\
0.089\end{array}$ & $\begin{array}{l}1.3 \\
0.8\end{array}$ & 20 & (a) \\
\hline Gymnodinium sp. & $\begin{array}{l}600 \text { to } \\
1200\end{array}$ & $\begin{array}{l}\text { Isochrysis galbana } \\
\text { Synechococcus sp. }\end{array}$ & $\begin{array}{l}1 \text { to } \\
51\end{array}$ & 0.41 & 0.7 & 12 & (b) \\
\hline Gyrodinium spirale & 11500 & Heterocapsa triquetra & 142 & 0.088 & 0.53 & 15 & (c) \\
\hline Gyrodinium dominans & $\begin{array}{l}20000 \text { to } \\
30000\end{array}$ & Chattonella antigua & 158 & 0.112 & 0.83 & 25 & (d) \\
\hline Protoperidinium hirobis & 5575 & Leptocylindrus danicus & & 0.147 & 1.23 & 20 & (e) \\
\hline Oblea rotunda & 6125 & Ditylum brightwellii & 53 & 0.062 & 0.66 & 20 & (f) \\
\hline $\begin{array}{l}\text { Protoperidinium } \\
\text { huberi }\end{array}$ & 38000 & Ditylum brightwellii & 741 & 0.134 & 0.72 & 20 & (g) \\
\hline $\begin{array}{l}\text { Protoperidinium cf. } \\
\text { divergens }\end{array}$ & 119000 & Gonyaulax polyedra & 720 & 0.043 & 0.48 & 19 & (h) \\
\hline P. crassipes & 204000 & Gonyaulax polyedra & 315 & 0.011 & 0.31 & 19 & (h) \\
\hline \multicolumn{8}{|l|}{ Estimated in situ rates } \\
\hline $\begin{array}{l}\text { Gymnodinium } \\
\text { sanguineum }\end{array}$ & $\begin{array}{l}6100 \mathrm{pg} \mathrm{C} \\
\left(43600 \mu^{3}\right)\end{array}$ & Nanociliates & $\begin{array}{l}\text { Max. } 30 \\
\text { Mean } 6.4\end{array}$ & 0.005 & - & 20 & (i) \\
\hline Gymnodinium sp. & $\begin{array}{l}1000 \text { to } \\
1500\end{array}$ & Phytoplankton & 6 & 0.033 & 0.3 & -1 & (j) \\
\hline \multicolumn{8}{|c|}{ 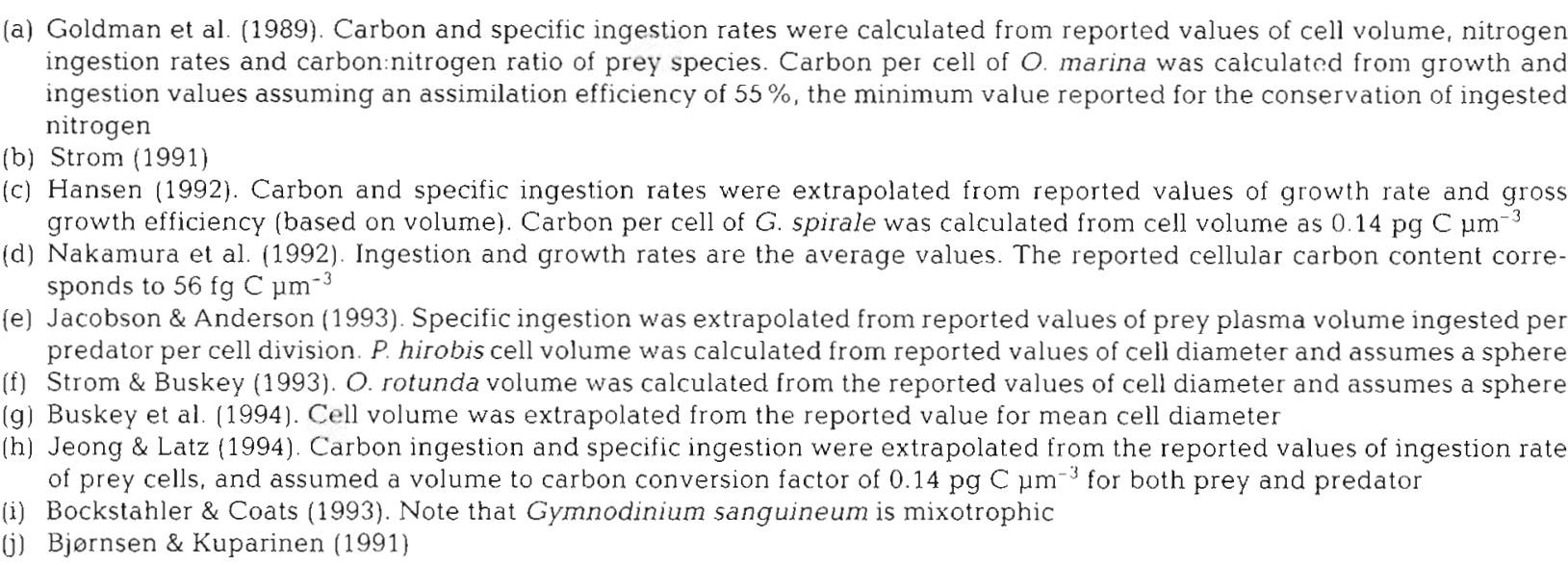 } \\
\hline
\end{tabular}

Jeong \& Latz 1994). In addition, prey concentration has been shown to affect grazing and growth rates in heterotrophic dinoflagellates in laboratory cultures /Goldman et al 1989, Strom 1991, Hansen 1992, Strom \& Buskey 1993, Buskey et al. 1994, Jeong \& Latz 1994). Sub-optimal prey types and prey concentrations for some of the 9 taxa of heterotrophic dinoflagellates may have occurred during the diatom bloom of the present study and this in part may explain the low estimates of grazing rates and the variation in growth rates among taxa.

The low water temperatures that occurred during the present study (Table 1) may also have contributed to the low estimated clearance, ingestion and growth rates. For example, Peters (1994) calculated a $Q_{10}$ of 2.14 for protist ingestion rates (prey predator ${ }^{-1} h^{-1}$ ) from literature values that spanned a temperature range of -1.5 to $26^{\circ} \mathrm{C}$. Using the same $Q_{10}$, ingestion rates of heterotrophic dinoflagellates measured at Davis would increase 4 -fold when extrapolated to temperatures commonly used for laboratory studies (Table 6). Such variation may result from the effect of temperature on enzyme reactions that govern rates of membrane synthesis and recycling involved in prey capture and/or ingestion (Capriulo \& Degan 1991) and digestion (Sherr et al. 1988). Interestingly, a study of different ecotypes of the heterotrophic nanoflagellate Paraphysomonas imperforata isolated from different 
latitudes illustrates that protists from polar waters may have partially adapted to compensate for low temperatures (Choi \& Peters 1992). There is also some indication that gross growth efficiencies may be higher in heterotrophic protists living at temperatures below their optimum temperature for growth (Choi \& Peters 1992).

\section{Heterotrophic dinoflagellate abundance and trophic role}

In the present study, the estimated biomass of the measured heterotrophic dinoflagellates reached a peak of $114.5 \mu \mathrm{g} \mathrm{Cl}^{-1}$ This was equivalent to $17 \%$ of the peak phytoplankton biomass and this proportion increased to $46 \%$ during the decline of the diatom bloom (Table 1 ). Estimates of the biomass of ciliates from water samples collected from the same place and time were in the re-

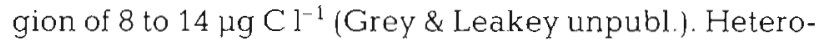
trophic dinoflagellates represented approximately 56 to $91 \%$ of the combined ciliate and heterotrophic dinoflagellate biomass during the present study.

The importance of heterotrophic dinoflagellates has also been demonstrated in blooms of large phytoplankton in a number of temperate eutrophic coastal regions (Smetacek 1981, Jacobson 1987, Lessard et al. 1988, Hansen 1991, Bralewska \& Witek 1995, Nakamura et al. 1995). For instance, the annual range of the percentage of heterotrophic dinoflagellate to combined ciliate and dinoflagellate biomass was between 5 and $62 \%$ in the Kiel Bight (Smetacek 1981), 2 and $85 \%$ in Perch Pond, Massachusetts (Jacobson 1987), 8 to $80 \%$ in Chesapeake Bay (Lessard 1991), 7 to $99 \%$ in the Kattegat (Hansen 1991) and approximately $80 \%$ in the Gulf of Gdansk (Bralewska \& Witek 1995). In the upwelling regions on the western edge of the Gulf Stream (Lessard 1991) and off the Oregon coast (Neuer \& Cowles 1994) large heterotrophic dinoflagellates have also been found to be the dominant protist grazers during periods when large phytoplankton were abundant. In addition, in the Seto Inland Sea heterotrophic dinoflagellate populations rapidly increased in response to the outbreak of a red tide and probably contributed to its disappearance (Nakamura et al. 1995).

Several studies of oligotrophic oceanic waters have found that dinoflagellates dominate the microzooplankton. In the surface waters of the northeastern Atlantic Ocean during mid-summer 1989, dinoflagellates contributed between 40 and $71 \%$ of the microzooplankton standing stocks with gymnodinioid forms accounting for the major part of the dinoflagellate biomass (Burkill et al. 1993a). Similarly, in surface waters of the Southern Ocean, 24 to $58 \%$ of the microzoo- plankton standing stock in the Bellingshausen Sea between $70^{\circ} 15^{\prime}$ and $67^{\circ} 30^{\prime} \mathrm{S}$ was composed of dinoflagellates (Burkill et al. 1995) and small (10 to $20 \mathrm{~m}$ ) gymnodinioid forms dominated the microzooplankton in surface waters of the Scotia-Weddell Confluence $\left(59^{\circ} 30^{\prime} \mathrm{S}\right)$ and Weddell Sea $\left(60^{\circ} 59^{\prime} \mathrm{S}\right)$ (Bjornsen \& Kuparinen 1991)

Although there are few directly comparable measurements, there is evidence that ciliates can grow faster than heterotrophic dinoflagellates of similar size (see review by Sherr \& Sherr 1994). Large heterotrophic dinoflagellates rather than ciliates dominate the microzooplankton during the blooms of large phytoplankton, perhaps due to their ability to feed on relatively large prey. The average linear size ratio between predator and optimum prey is approximately $1: 1$ for heterotrophic dinoflagellates, $8: 1$ for ciliates and 18:1 for copepods (Hansen et al. 1994), suggesting that small $(<20 \mu \mathrm{m})$ heterotrophic dinoflagellates may compete for prey with larger ciliates capable of similar growth rates. Larger $(>20 \mu \mathrm{m}$ ) heterotrophic dinoflagellates may compete with copepods for larger prey. The faster growth of heterotrophic dinoflagellates compared to metazoan zooplankton may allow them to respond more rapidly to phytoplankton blooms.

The pattern of heterotrophic dinoflagellate abundance and grazing activity observed in the present study illustrates that heterotrophic dinoflagellates can respond rapidly to phytoplankton growth in Antarctic coastal waters (Figs, 4 \& 6, Table 4). The maximum estimated ingestion rate of the heterotrophic dinoflagellate population of $32.8 \mu \mathrm{g} \mathrm{C} \mathrm{C}^{-1} \mathrm{~d}^{-1}$ on 31 January (Table 4) coincided with the peak of the diatom bloom during the end of January and beginning of February (Fig. 2). This maximum daily ingestion rate represented an estimated $4.8 \%$ of the autotrophic standing stock and as the phytoplankton biomass declined the proportion consumed increased to almost $14 \%$ (Table 4). That heterotrophic dinoflagellates are major consumers of phytoplankton carbon and have a significant impact on phytoplankton production has been illustrated in a number of previous studies. Microcosm experiments conducted in the Weddell Sea and Weddell-Scotia Confluence suggested that heterotrophic dinoflagellates may contribute significantly to keeping phytoplankton biomass low in the Southern Ocean (Bjørnsen \& Kuparinen 1991). In the Bellingshausen Sea and northeast Atlantic Ocean, respective daily phytoplankton turnovers of 3 to $40 \%$ (Burkill et al. 1995) and 2 to $45 \%$ (Burkill et al. 1993a) were recorded. As mentioned previously, in both cases heterotrophic dinoflagellates were a major component of the microzooplankton population.

Grazing impact on phytoplankton may also be expressed in terms that compare the rate of consump- 
tion with the rate of production, i.e. as the proportion of daily primary production consumed per day. In the present study the equivalent of an estimated $25 \%$ of the primary production, measured as the rate of ${ }^{14} \mathrm{C}$ incorporation (Robinson et al. unpubl.), was consumed daily during the peak of phytoplankton standing stock (Table 4). During periods of upwelling along the coast of Oregon, rates of herbivory measured by a dilution technique were closely coupled to the abundance of gymnodinioid dinoflagellates and varied between 18 and $52 \%$ of the estimated primary production at a depth of between 7 and $9 \mathrm{~m}$ (Never \& Cowles 1994). Similarly, Oblea rotunda was estimated to clear up to $53 \%$ of primary production in Chesapeake Bay (Lessard et al. 1988). Even more valuable information may be gained if ingestion and primary production rates can be integrated throughout the mixed layer depth. For instance, over the mixed layer in the Bellingshausen Sea (Burkill et al. 1995) and northeast Atlantic Ocean (Burkill et al. 1993a) microzooplankton, including a large proportion of dinoflagellates, consumed an estimated 21 to $271 \%$ and 39 to $115 \%$ of the phytoplankton production per day respectively. Measurements carried out in the present study and by Robinson et al. (unpubl.) were limited to the $5 \mathrm{~m}$ depth at $\mathrm{O}^{\prime} \mathrm{Gor}$ man Rocks. However, year-round sampling carried out throughout the $20 \mathrm{~m}$ deep water column illustrated some variation in the abundance and composition of the microzooplankton population through the water column at $\mathrm{O}^{\prime}$ Gorman Rocks (Grey et al. unpubl.), suggesting that total ingestion rates and the contribution of the various components of the microzooplankton to the grazing impact may vary with depth.

In conclusion, despite the potential biases mentioned above, the radioisotope tracer technique employed in the present study produced some of the first estimates of in situ grazing rates of heterotrophic dinoflagellates at in situ predator and prey concentration and at the taxon-specific level. The estimated rates of specific ingestion and growth of heterotrophic dinoflagellates were low in the coastal waters of East Antarctica, compared to laboratory studies carried out at higher temperatures. However, when the environmental parameters, predator size and prey type and concentration are taken into account, values measured in the present study are tenable and comparable to other in situ measurements. Abundance, biomass and heterotrophic dinoflagellate population grazing pressure was dominated by 3 taxa, Gyrodinium sp. 1 and sp. 2 and the armoured Diplopeltopsis spp. The heterotrophic dinoflagellate population increased in response to the phytoplankton bloom that occurred during the study period and exerted a maximum grazing pressure that coincided with the peak of autotrophic biomass. Approximately $25 \%$ of primary production was esti- mated to have been consumed each day by heterotrophic dinoflagellates during maximum phytoplankton biomass. This shows that heterotrophic dinoflagellates play an important part in the biotic control of phytoplankton production and phytogenic carbon flux in the coastal waters of East Antarctica.

Acknowledgements. We thank Carol Robinson and Jon Grey for field assistance, and acknowledge the considerable support of the Australian Antarctic Division, in particular Harvey Marchant and Andrew I)avidson, and all the friends and colleagues who made up A.N.A.R.E. at Davis during 1993/94. We are also grateful to 3 anonymous reterees for critically reading the manuscript. This work was supported by Antarctic Special Topic Grant (GST/02/0656) from the British Antarctic Survey (Natural Environment Research Council) to M.A.S., P.H.B. and R.J.G.L.

\section{LITERATURE CITED}

Archer SD, Leakey RJG, Burkill PH, Sleigh MA, Appleby CJ (1996) Microbial ecology of sea ice at a coastal Antarctic site: community composition, biomass and temporal change. Mar Ecol Prog Ser 135:179-195

Arrigo KR, McClain CR (1994) Spring phytoplankton production in the Western Ross Sea. Science 266:261-263

Balech E (1975) Clave illustrada de dinoflagelados antárticos. Instituto Antartico Argentino, Buenos Aires, p 90

Barlow RG, Burkill PH, Mantoura RFC (1988) Grazing and degradation of algal pigments by marine protozoan Oxyrrhis marina. J Exp Mar Biol Ecol 119:119-129

Becquevort S, Mathot S, Lancelot C (1992) Interactions in the microbial community of the marginal ice zone of the northwestern Weddoll Sea through size distribution analysis. Polar Biol 12:211-218

Bjornsen PK, Kuparinen J (1991) Growth and herbivory by heterotrophic dinoflagellates in the Southern Ocean, studied by microcosm experiments. Mar Biol 109: $397-405$

Bockstahler KR, Coats DW (1993) Grazing of the mixotrophic dinoflagellate Gymnodinium sangumeum on ciliate populations of Chesapeake Bay. Mar Biol 116:477-487

Bralewska JA, Witek K (1995) Heterotrophic dinoflagellates in the ecosystem of the gulf of Gdansk. Mar Ecol Prog Ser $117: 241-248$

Burkill PH, Edwards ES, John AWG, Sleigh MA (1993a) Microzooplankton and their herbivorous activity in the northeastern Atlantic Ocean. Deep Sea Res II 40:479-494

Burkıll PH, Edwards ES, Sleigh MA (1995) Microzooplankton and their role in controlling phytoplankton growth in the marginal ice zone of the Bellingshausen Sea. Deep Sea Res II 42:1277-1290

Burkill PH, Leakey RJG, Owens NJP, Mantoura RFC (1993b) Synechococcus and its importance to the microbial foodweb of the northwest Indian Ocean. Deep Sea Res II 40:773-782

Buskey EJ, Coulter CJ, Brown SL (1994) Feeding, growth, and broluminescence of the heterotrophic dinoflagellate Protoperidinum huberi. Mar Biol 121:373-380

Caprulo GMi Degan C (1991) Effect of food concentration on digestion and vacuole passage time in the heterotrichous marine ciliate Fibrea salina. Mar Biol 110:199-202

Capriulo GM, Sherr EB, Sherr BF (1991) Trophic behaviour and related community feeding activities of heterotrophic marine protists. In: Reid PC, Turley CM, Burkill PH (eds) 
Protozoa and their role in marine processes. NATO ASI Series G 25, Springer-Verlag, Berlin, p 219-265

Choi JW, Peters F (1992) Effects of temperature on two psychrophilic ecotypes of a heterotrophic nanoflagellate, Paraphysomonas imperforata. Appl Environ Microbiol 58:593-599

Clarke A, Leakey RJG (in press) The seasonal cycle of phytoplankton macronutrients and the microbial community in a nearshore Antarctic marine ecosystem. Limnol Oceanogr

Daro MH (1978) A simplified ${ }^{14} \mathrm{C}$ method for grazing measurements on natural planktonic populations. Helgoländer Wiss Meeresunters 31:241-248

Daro MH, Baars MA (1986) Calculations of zooplankton grazing rates according to a closed, steady-state, three compartment model applied to different ${ }^{14} \mathrm{C}$ methods. Hydrobiol Bull 19:159-170

Davidson AT, Marchant HJ (1992) Protist abundance and carbon concentration during a phaeocystis-dominated bloom at an Antarctic coastal site. Polar Biol 12:387-395

Dodge JD (1982) Marine dinoflagellates of the British Isles. Her Majesty's Stationery Office, London

Elbrächter $M$ (1991) Food uptake mechanisms in phagotrophic dinoflagellates and classification. In: Patterson DJ, Larsen J (eds) The biology of free-living heterotrophic flagellates. (Systematics Association Spec Vol 45), Clarendon Press, Oxford, p 303-312

Frost BW (1991) The role of grazing in nutrient-rich areas of the open sea. Limnol Oceanogr 36:1616-1630

Gaines G, Elbrächter M (1987) Heterotrophic nutrition. In: Taylor FJR (ed) The biology of dinoflagellates. Blackwell. Oxford, p 224-268

Gifford DJ (1988) Impact of grazing by microzooplankton in the Northwest Arm of Halifax Harbour, Nova Scotia. Mar Ecol Prog Ser 47:249-258

Goldman JC, Dennett MR, Gordin H (1989) Dynamics of herbivorous grazing by the heterotrophic dinoflagellate Oxyrrhis marina. J Plankton Res 11:391-407

Hansen B, Bjornsen PK, Hansen PJ (1994) The size ratio between planktonic predators and their prey. Limnol Oceanogr 39:395-403

Hansen PJ (1991) Quantitative importance and trophic role of heterotrophic dinoflagellates in a coastal pelagial food web. Mar Ecol Prog Ser 73:253-261

Hansen PJ (1992) Prey size selection feeding rates and growth dynamics of heterotrophic dinoflagellates with special emphasis on Gyrodinium spirale Mar Biol 114:327-334

Hayes PK, Whitaker TM, Fogg GE (1984) Distribution and nutrient status of phytoplankton in the Southern Ocean between 20 and $70^{\circ} \mathrm{W}$. Polar Biol 3:153-165

Hewes CD. Sakshaug E, Reid FMH. Holm-Hansen O (1990) Microbial autotrophic and heterotrophic eucaryotes in Antarctic waters: relationships between biomass and chlorophyll, adenine triphosphate and particulate organic carbon. Mar Ecol Prog Ser 63:27-35

Jacobson DM (1987) The ecology and feeding behaviour of thecate heterotrophic dinoflagellates. PhD thesis, Massachusetts Institute of Technology and Woods Hole Oceanographic Institution

Jacobson DM, Anderson DM (1993) Growth and grazing rates of Protoperidinium hirobis Abé, a thecate heterotrophic dinoflagellate. J Plankton Res 15:723-736

Jacques G (1989) Primary production in the open Antarctic ocean during the austral summer. A review. Vie Milieu 39: $1-17$

Jeong HJ (1994) Predation by the heterotrophic dinoflagellate Protoperidinium cf. divergens on copepod eggs and early naupliar stages. Mar Ecol Prog Ser 114:203-208
Jeong HJ, Latz MI (1994) Growth and grazıng rates of the heterotrophic dinoflagellates Protoperidinium spp. on red tide dinoflagellates. Mar Ecol Prog Ser 106:173-185

Knox GA (1990) Primary production and consumption in McMurdo Sound, Antarctica. In: Kerry KR, Hempel G (eds) Antarctic ecosystems. Ecological change and conservation. Springer-Verlag, Berlin, p 115-128

Kopczyńska EE, Goeyens L, Semeneh M, Dehairs F (1995) Phytoplankton composition and cell carbon distribution in Prydz Bay, Antarctica: relation to organic particulate matter and its $\delta^{13} \mathrm{C}$ values. J Plankton Res 17:685-707

Kuparinen J, Bjørnsen PK (1992) Bottom-up and top-down controls of the microbial food web in the Southern Ocean: experiments with manipulated microcosms. Polar Biol 12: $189-195$

Landry MR (1994) Methods and controls for measuring the grazing impact of planktonic protists. Mar Microb Food Webs 8:37-57

Leakey RJG, Archer SD, Grey J (in press) Microbial dynamics in coastal waters of eastern Antarctica: bacterial production and nanoflagellate bacterivory. Mar Ecol Prog Ser

Lessard EJ (1991) The trophic role of heterotrophic dinoflagellates in diverse marine environments. Mar Microb Food Webs 5:49-58

Lessard EJ, Brownlee DC, Sellner K, Caron DA (1988) Role of microzooplankton biomass, growth, and grazing in plankton dynamics in Chesapeake Bay. EOS 69:1103

Lessard EJ, Rivkin RB (1986) Nutrition of microzooplankton and macrozooplankton from MCMurdo Sound. Antarct I US 21:187-188

Lessard EJ, Swift E (1985) Species-specific grazing rates of heterotrophic dinoflagellates in oceanic waters, measured with a dual radioisotope technique. Mar Biol 87:289-296

Lessard EJ, Swift E (1986) Dinoflagellates from the North Atlantic classufied as phototrophic or heterotrophic by epifluorescence microscopy. J Plankton Res 8:1209-1215

Middleton JH, Humphries SE (1989) Thermohaline structure and mixing in the region of Prydz Bay, Antarctica. Deep Sea Res 36:1255-1266

Montagna PA (1984) In situ measurement of meiobenthic grazing rates on sediment bacteria and edaphic diatoms. Mar Ecol Prog Ser 18:119-130

Murphey EJ, Boyd PW, Leakey RJG, Atkinson A, Edwards ES, Robinson C, Priddle J, Bury SJ, Robins DB, Burkill PH, Savidge G, Owens NJP, Turner D (in press) Carbon flux in ice ocean plankton systems of the Bellingshausen Sea during a period of ice retreat. J Mar Syst

Nakamura Y, Suzuki S, Hiromi J (1995) Population dynamics of heterotrophic dinoflagellates during a Gymnodinium mikimotor red tide in the Seto Inland Sea. Mar Ecol Prog Ser 125:269-277

Nakamura Y, Yamazaki Y, Hiromi J (1992) Growth and grazing of a heterotrophic dinoflagellate, Gyrodinium dominans, feeding on a red tide flagellate, Chattonella antiqua. Mar Ecol Prog Ser 82:275-279

Neuer S, Cowles TJ (1994) Protist herbivory in the Oregon upwelling system. Mar Ecol Prog Ser 113:147-162

Never S, Cowles TJ (1995) Comparative size-specific grazing rates in field populations of ciliates and dinoflagellates. Mar Ecol Prog Ser 125:259-267

Öpik H, Flynn KJ (1989) The digestive process of the dinofla gellate, Oxyrrhis marina Dujardin, feeding on the chlorophyte, Dunaliella primolecta Butcher: a combined study of ultrastructure and free amino acids. New Phytol 113:143-151

Paranjape MA (1990) Grazing by microzooplankton in the eastern Canadian Arctic in summer 1983. Mar Ecol Prog Ser 40:239-246 
Perrin RA, Lu P, Marchant HJ (1987) Seasonal variation in marine phytoplankton and ice algae at a shallow Antarctic coastal site. Hydrobiologia 146:33-46

Peters F (1994) Prediction of planktonic protistan grazing rates. Limnol Oceanogr 39:195-206

Priddle J. Smetacek V. Bathmann U (1992) Antarctic marine primary production, biogeochemical carbon cycles and climatic change. Phil Trans R Soc Lond B 338:289-297

Rivkin RB, Seliger HH (1981) Liquid scintillation counting for ${ }^{14} \mathrm{C}$ uptake of single algal cells isolated from natural samples. Limnol Oceanogr 26:780-785

Rublee PA, Gallegos CL (1989) Use of fluorescently labelled algae (FLA) to estimate microzooplankton grazing. Mar Ecol Prog Ser 51:221-227

Satoh H, Watanabe K. Hoshiai T (1991) Estimates of primary production by ice algae and phytoplankton in the coastal ice-covered area near Syowa Station, Antarctica. Antarct $\operatorname{Rec}$ 35:30-38

Sekiguchi H, Kato T (1976) Influence of Noticula's predation on the Acartia population in the Ise Bay. Central Japan. J Oceanogr Soc Japan 32:195-198

Shapiro LP, Haugen EM, Carpenter EJ (1989) Occurrence and abundance of green-fluorescing dinoflagellates in surface waters of the Northwest Atlantic and Northeast Pacific J Phycol 25:189-191

Sherr BF, Sherr EB, Rassoulzadegan F (1988) Rates of digestion of bacteria by marine phagotrophic protozoa: temperature dependence. Appl Environ Microbiol 54:1091-1095

Sherr EB, Sherr BF (1994) Bacterivory and herbivory: key roles of phagotrophic protists in pelagic food webs. Microb Ecol 28:223-235

Simonnet G (1990) The scintillation counter. In: Slater RJ (ed) Radioisotopes in biology. A practical approach. Oxford University Press, Oxford, p 31-85

This article was submitted to the editor
Smetacek $V(1981)$ The annual cycle of protozooplankton in the Kiel Bight. Mar Biol 63:1-11

Smith WO Jr (1987) Phytoplankton dynamics in marginal ice zones. Oceanogr Mar Biol A Rev 25:11-38

Strickland JDH, Parsons TR (1972) A practical handbook of seawater analysis. Bull Fish Res Bd Can 167

Strom SL (1991) Growth and grazing rates of the herbivorous dinoflagellate Gymnodinium sp. from the open subarctic Pacifıc Ocean. Mar Ecol Prog Ser 78:103-113

Strom SL, Buskey EJ (1993) Feeding, growth, and behaviour of the thecate heterotrophic dinoflagellate Oblea rotunda. Limnol Oceanogr 38:965-977

Tackx MLM, Daro MH (1993) Influence of size dependent ${ }^{14} \mathrm{C}$ uptake rates by phytoplankton cells in zooplankton grazing measurements. Cah Biol Mar 34:253-260

Tréguer P, Jacques G (1992) Dynamics of nutrents and phytoplankton, and fluxes of carbon, nitrogen and silicon in the Antarctic Ocean. Polar Biol 12:149-162

Utermöhl H (1958) Zur Vervollkommnung der quantitativen Phytoplankton-Methodik. Mitt Int Verein Theor Angew Limnol 9:1-38

Watson AJ, Robinson C, Robertson JE, Williams PJ leB, Fasham MJR (1991) Spatial variability in the sink for atmospheric carbon dioxide in the North Atlantic. Nature 350: $50-53$

Williams PJ leB (1993) Chemical and tracer methods of measuring plankton production. In: Li WKW, Maestrini SY (eds) Measurement of primary production from the molecular to the global scale. ICES Mar Sci Symp 197: $20-36$

Zubkov MV, Sleigh MA (1995) Bacterivory by starved marine heterotrophic nanoflagellates of two species which feed differently estimated by uptake of dual radioactivelabelled bacteria. FEMS Microb Ecol 17:57-66

Manuscript first received: December 20, 1995

Revised version accepted: April 19, 1996 